\title{
ONIFACIO FERRER. SU VENERACIÓN A D TRAVÉS DE LAS IMÁGENES
}

ANDRÉS FELICI CASTELL

Fundación de la Comunidad Valenciana. Escuelas del Ave María (Carcaixent) andres.felici@uv.es

\begin{abstract}
Resumen: Bonifacio Ferrer (1355-1417) fue un destacado personaje de la Corona Aragonesa, recordado por ser una persona de confianza del papa Luna, por haber participado en el Compromiso de Caspe (1412), por haber ocupado el cargo de General de la Orden Cartuja, por haber traducido la Biblia al valenciano o por ser hermano de san Vicente Ferrer. Debido a eso, y a otros motivos, tras su fallecimiento fue considerado como "santo" en algunos lugares, aunque nunca se llegó a iniciar un proceso de canonización oficial, como sí que ocurrió con su hermano Vicente, por lo que los autores posteriores lo calificaron como "venerable". Ese culto ha dejado como testimonio diversas imágenes que todavía hoy conservamos, realizadas entre los siglos XIV$\mathrm{XX}$, que se concentran fundamentalmente en torno a tres lugares muy relacionados con su biografía: la cartuja de Portaceli, la de Valldecrist y la ciudad de Valencia. A partir de su estudio podremos conocer la importancia y el desarrollo que tuvo la ininterrumpida veneración al venerable Bonifacio Ferrer a lo largo de los siglos.
\end{abstract}

Palabras claves: Bonifacio Ferrer / Venerable / Iconografía / Cartuja de Portaceli / Cartuja de Valldecrist.

\section{BONIFACIO FERRER. HIS WORSHIP THROUGH IMAGES}

Abstract: Bonifacio Ferrer (1355-1417) was a prominent personality of the Crown of Aragon. He was a trusted person for Pope Luna, took part in the Compromise of Caspe (1412), held the position of General of the Order Cartuja, translated the Bible into Valencian and his brother was Saint Vicente Ferrer. Because all of that, and among other reasons, after his death he became considered a "saint" in some places, despite an official canonization process was never started (not like his brother's), and some following authors described him as "venerable". This cult left some images painted between fourteenth and twentieth century that are still preserved today. These images are focused mainly on three places strongly related to his biography: Portaceli's cartuja, Valldecrist's cartuja and the city of Valencia. From the study of these images we'll be able to know the importance and development that the continuous worship of Bonifacio Ferrer had.

Key words: Bonifacio Ferrer / Venerable / Iconography / Cartuja de Portaceli / Cartuja de Valldecrist.

La figura de Bonifacio Ferrer ha permanecido en la memoria valenciana por diversos motivos, fundamentalmente de carácter histórico -su participación en el Compromiso de Caspe, el hecho de haber sido el primer valenciano en regentar la Orden de la Cartuja, su hipotética participación en la traducción de la Biblia al valenciano, el hecho de ser el hermano de san Vicente Ferrer...-. Pero en algunos lugares la figura de Bonifacio tuvo una relevancia singular que fue más allá de los meros acontecimientos históricos, puesto que llegó a ser venerado casi como un santo. Pese a que nunca gozó de un reconocimiento oficial por parte de la Iglesia, de ahí que popularmente se le califique como "venerable", ${ }^{1}$ en algunos focos concretos se le ensalzó de tal manera que poco tuvo que envidiar a otros compañeros canonizados. Hoy en día de esta veneración apenas nos quedan vestigios, pero unos de los más importantes, que nos pueden ayudar a hacernos una idea del culto que pu-

\footnotetext{
* Fecha de recepción: 15 de octubre de 2017 / Fecha de aceptación: 23 de mayo de 2018.

1 Sobre el concepto de "venerable" y cómo lo entendemos en el presente trabajo, ver: FELICI CASTELL, Andrés, La santidad local valenciana: la tradición de sus imágenes y su alcance cultural. Tesis doctoral. Universidad de Valencia, 2016, pp. 26-59.
} 
do llegar a tener el venerable cartujo, son las imágenes que se realizaron.

\section{Bonifacio Ferrer (1355-1417)}

Nacido en 1355 en la ciudad del Turia y bautizado en la parroquia de San Esteban, fue el tercer hijo varón de Guillermo Ferrer, notario, y de Constanza Miquel, oriundos de Cataluña, y por tanto hermano menor de san Vicente Ferrer (1350-1419). En Valencia estudió Gramática, Lógica y Artes en alguna escuela patrocinada por la autoridad eclesiástica. A los nueve años obtuvo el beneficio eclesiástico instituido en la catedral de Valencia con la invocación de San Antonio, que se le confirió el 3 de enero de 1363, y a los trece el de Santa Ana, en la iglesia de Santo Tomás, por la renuncia que hizo su hermano san Vicente el 27 de abril de 1367. Posiblemente poco después se trasladaría a Lleida a estudiar jurisprudencia y marcharía a continuación a Perusa, probablemente como alumno becado, donde fue discípulo del célebre jurisconsulto Baldo degli Ubaldi. En 1375 regresó, por huir del motín de Pisa contra Gregorio XI, concluyó su doctorado en ambos derechos en Lleida y, según algunos autores, también se doctoró en Teología. En 1376 ya aparece en Valencia regentan- do una cátedra de derecho canónico creada por su obispo Jaime de Aragón en el palacio episcopal. Bonifacio combinó este trabajo con el ejercicio de la abogacía en favor del municipio, de otras localidades y de la curia episcopal, alcanzando gran fama.

En 1382 se desposó con Jaumeta Despont, de familia noble y rica, con quien tuvo cuatro hijos y siete hijas. Entre 1387 y 1389 ejerció el cargo de Jurado de la Ciudad, dentro de la clase de ciudadanos, y en 1388 compró el municipio de Alfara por 35.000 sueldos. Ese mismo año fue enviado, junto con otros cuatro juristas, como representante de la ciudad a las Cortes de Monzón, convocadas por el rey Juan I, donde surgió un enfrentamiento entre familias nobles que acabó con un proceso de condena a estos juristas por parte del monarca, el cual los encarceló, embargó sus bienes y los devolvió a Valencia para su procesamiento. ${ }^{3}$ El proceso se alargó varios años y mientras tanto, se cree que a causa de una epidemia, en 1394 fallecieron su esposa y sus siete hijas, que se sumaron a la pérdida de otros dos hijos varones, Pablo y Lucas, producida con anterioridad. El 6 de noviembre de 1395, después de seis años, Bonifacio confesó su culpa y tras quedar en libertad,

\footnotetext{
2 Pese a la importancia del personaje, todavía no existe ninguna biografía exhaustiva, completa y rigurosa sobre el mismo, aunque sí que hay numerosos autores que refieren datos suyos en diferentes obras, especialmente en las biografías de su hermano san Vicente Ferrer (ANTIST, Vicente Justiniano, La Vida, y Historia del Apostolico Predicador sant Vincente Ferrer Valenciano, de la orden de sancto Domingo. Valencia: Pedro de Huete, 1575, pp. 292-295; DIAGO, Francisco, Historia de la vida, milagros, muerte, y discipulos del bienaventurado predicador apostólico Valenciano S. Vicente Ferrer de la Orden de Predicadores... Barcelona: Gabriel Graells y Giraldo Dotil, 1600, pp. 167-171; FERRER DE VALDECEBRO, Andrés, Historia de la vida maravillosa, y admirable del segundo Pablo, Apostol de Valencia, S. Vicente Ferrer. Barcelona: Vicente Suría, 1718, pp. 3-7; VIDAL MICÓ, Francisco, Historia de la portentosa vida, y milagros del valenciano Apóstol de Europa S. Vicente Ferrer... Valencia: José Esteban Dolz, 1735, pp. 418-422), en recopilatorios sobre escritores valencianos (ANTONIO, Nicolás, Bibliotheca hispana vetus... Madrid: Joaquín Ibarra, 1788, t. 2, pp. 213-214; RODRÍGUEZ, José, Biblioteca Valentina. Valencia: José Tomás Lucas, 1747, pp. 87-91; XIMENO, Vicente, Escritores del Reino de Valencia... Valencia: Joseph Estevan Dolz, 1747, t. 1, pp. 20-24; PASTOR FUSTER, Justo. Biblioteca Valenciana de los Escritores que florecieron hasta nuestros días. Con adiciones y enmiendas a la de D. Vicente Ximeno. Valencia: José Ximeno, 1827, t. 1, pp. 15-16), o en fuentes y estudios sobre la orden cartuja [De Rebus Monasterii Porta-Coeli, manuscrito, s. XVIII (ed. RIBES TRAVER, Ma Estrella, Los Anales de la Cartuja de Porta-Coeli. Valencia: Institución Alfonso el Magnánimo, Diputación, 1998, pp. 101 y 103); LE VASSEUR, Leone, Ephemerides Ordinis Cartusiensis. Monstrolii: Typis Cartusiaes S. Mariae de Pratis, 1890, vol. 1, pp. 519-541; FUSTER SERRA, Francisco, Cartuja de Portaceli. Historia, vida, arquitectura y arte. Valencia: Ayuntamiento, 2003, pp. 121-122 y 136-146; FERRER ORTS, Albert, "El esplendor de Portaceli y Valldecrist en el siglo XV. Unas notas sobre Bonifacio Ferrer". En: CANTERA MONTENEGRO, Santiago et al. La cartuja de Valldecrist, VI Centenario de la Obra Mayor. Salzburgo: ICAP, Analecta cartusiana, 2008, pp. 131-138; FUSTER SERRA, Francisco, Legado artístico de la Cartuja de Portaceli. Obras, iconografía, benefactores y artífices en su contexto histórico. Salzburgo: Universidad de Salzburgo, 2012, pp. 31-37]. Para este breve resumen nos hemos basado fundamentalmente en la publicación más reciente: ESPONERA CERDÁN, Alfonso (ed.), Bonifacio Ferrer, un valenciano muy poco conocido. Valencia: Institució Alfons el Magnànim, 2013; donde se recogen diferentes artículos de diversos autores publicados en otros libros o revistas en los últimos años, o documentos de difícil consulta [TEIXIDOR, José, Vida de San Vicente Ferrer, Apóstol de Europa (1775). Valencia: Ayuntamiento, 1999; GÓMEZ GARCíA, Vito-Tomás, "La figura de Bonifacio Ferrer". Escritos del Vedat, n 10, 1980, pp. 268-280; LLOP CATALÁ, Miguel, "Proceso de Bonifacio Ferrer". Escritos del Vedat, n 10, 1980, pp. 415-471; MORRO FOSAS, Pedro, D. Bonifacio Ferrer. Su vida-sus obras. Segorbe, 1955; ALMINYANA VALLÉS, Josep, Vida y obra de Bonifaci Ferrer. Valencia: Academia de Cultura Valenciana, 1997; PARDO ENGUER, José, "Fray Bonifacio Ferrer, el hermano de San Vicente". Glorias Vicentinas. Valencia, 2005, pp. 22-25].

${ }^{3}$ Sobre este proceso ver: LLOP CATALÁ, Miguel, "Proceso de Bonifacio Ferrer". En: ESPONERA CERDÁN, Alfonso (ed.), 2013 (nota 2), pp. 45-103 (o en: Escritos del Vedat, 1980, n 10, pp. 415-471); GARCíA, Angelina, "Las crisis del siglo XIV valenciano y Bonifacio Ferrer". En: GARCÍA GONZÁLEZ, Juan, et al. Estudios de Historia de Valencia. Valencia: Universidad de Valencia, 1978, pp. 81-89.
} 
vendió el lugar de Alfara, encomendó el cuidado de sus dos hijos que le quedaban, Juan y Francis$\mathrm{co}$, a su hermana Constanza y por consejo de su hermano san Vicente tomó el hábito de cartujo en Portaceli el 21 de marzo de 1396. Su profesión fue el 24 de junio del mismo año, con dispensa papal, y recibió los órdenes el 22 de julio. En 1398 fue maestro de novicios, falleciendo también su hijo menor, Francisco, el año siguiente fue elegido procurador y el 8 de enero de 1400 fue nombrado prior. Posiblemente durante estos años de estancia en Portaceli fue cuando un equipo de monjes, dirigidos por Bonifacio, se encargó de traducir la Biblia al valenciano, según señalan algunos autores. El marzo siguiente acudió al capítulo general de la orden en la Gran Cartuja de Grenoble, y visitó a su regreso en Aviñón a su amigo el papa Benedicto XIII, el cual le pidió que permaneciera en su compañía enviándole como embajador ante Carlos VI, rey de Francia.

El 23 de junio de 1402 Bonifacio fue nombrado General de la Cartuja, debido al fallecimiento de su predecesor, y tomó posesión del cargo al año siguiente. Participó como delegado del sumo pontífice en el concilio de Pisa en 1409, aunque con poco éxito. A raíz de éste, el 21 de marzo de 1410, Bonifacio renunció a su cargo de General, tal y como hizo su homónimo partidario de Gregorio XII, Esteban Mazonio, con la intención de unificar el cargo. Pero Benedicto XIII se opuso a esta decisión, le obligó a continuar en el generalato y trasladó su residencia a la cartuja de Valldecrist, en la localidad de Altura, cerca de Segorbe. En 1412 tomó parte en el Compromiso de Caspe en representación del Reino de Valencia, otorgando su voto a Fernando de Antequera, como su hermano san Vicente. Durante esta ausencia su hijo Juan tomó el hábito en dicho monasterio, convirtiéndose Bonifacio a su regreso en su maestro de novicios. En 1415 marchó a Perpiñán junto con su santo hermano cooperando por la paz y la unión de la Iglesia, mediando para que diversos príncipes retiraran la obediencia al reticente Benedicto XIII, y lograron que así lo hiciera la Corona de Aragón el 6 de enero de 1416. Después se retiró a Valldecrist, donde falleció el 27 de abril de 1417 y fue sepultado en el cementerio del claustro, que había sido consagrado poco tiempo antes, siendo el primero en ser enterrado allí, cerca de la torre de Almas.

Pese a que no se conoce ningún milagro realizado en vida ${ }^{4} \mathrm{ni}$ se le inició un proceso de canonización tras su muerte, todo lo contrario que su hermano san Vicente, hoy en día conservamos una considerable cantidad de imágenes de Bonifacio Ferrer elaboradas la mayoría con posterioridad a su fallecimiento, incluso varios siglos después, algunas de las cuales pueden confirmar que existió una veneración hacia su persona. Dejando aparte las representaciones de episodios históricos como el Compromiso de Caspe, se pueden señalar tres focos en los que se realizó una notable producción de imágenes: la cartuja de Portaceli, la ciudad de Valencia y la cartuja de Valldecrist-Altura.

\section{La cartuja de Portaceli}

El 21 de marzo de 1396 Bonifacio tomó el hábito en la cartuja de Portaceli de la mano de su prior Pedro Julián, y profesó, mediante dispensa papal, el 24 de junio del mismo año debido a su avanzada edad y estudios. Como muestra de agradecimiento hacia la orden y el monasterio, con sus rentas mandó edificar una capilla en el claustro de la cartuja que dedicó a la Santa Cruz y adornó con cáliz, retablo y otros ornamentos, consagrándose el 24 de febrero de $1397 .{ }^{5}$ Dicho retablo actualmente se atribuye ${ }^{6}$ a un artista italiano que estuvo instalado en Valencia entre 1395 y 1401: ${ }^{7}$ Gherardo di Jacopo Starnina. ${ }^{8}$ Bonifacio dispon-

\footnotetext{
${ }^{4}$ El padre Civera refiere un único acontecimiento sobrenatural en su biografía: la aparición de un ángel ante un titubeo vocacional. CIVERA, Juan Bautista. Segunda parte de los Anales de la cartuja de Portaceli..., ca. 1645, fol. 73. Citado en: FERRE DOMínGUEZ, Josep-Vicent, Joan Baptista Civera, el cronista de Portaceli. Salzburg: Institut für Anglistik und Amerikanistik, Universität Salzburg, 2004, p. 154.

5 De Rebus Monasterii Porta-Coeli, s. XVIII (nota 2), p. 101; FUSTER SERRA, Francisco, 2012 (nota 2), p. 35; LLANES DOMINGO, Carme, L'Obrador de Pere Nicolau. L'estil gòtic internacional a València (1390-1408). Valencia: Universidad de Valencia, 2014, pp. 84-85.

${ }^{6}$ Sobre las diferentes atribuciones realizadas a lo largo de la historia, ver: PALUMBO, Maria, Il soggiorno di Gherardo Starnina in Spagna. Tesis Doctoral. Universidad de Barcelona, 2015, pp. 356-360.

7 MIQUEL JUAN, Matilde, Retablos, prestigio y dinero. Talleres y mercado de pintura en la Valencia del gótico internacional. Valencia: Universidad de Valencia, 2008, p. 92.

${ }^{8}$ Existen diversos estudios sobre dicho retablo, algunos de ellos: RODRÍGUEZ CULEBRAS, Ramón, "El retablo de Fray Bonifacio Ferrer, pieza clave en la iconografía sacramentaria del arte valenciano". Archivo de Arte Valenciano, 1978, n 49, pp. 1217; RODRIGO ZARZOSA, Carmen, "En torno al retablo de Fray Bonifacio Ferrer". Archivo de Arte Valenciano, 1985, n 66, pp. 30-33; GARCÍA BORRÁS, Ximo, "En torno al retablo de fray Bonifacio Ferrer". Archivo de Arte Valenciano, nº6, 1988, pp. 2731; BRANDON STREHLKE, Carl, "Gherardo Starnina. Retablo de Bonifacio Ferrer". En: BENITO DOMÉNECH, Fernando; GÓMEZ
} 


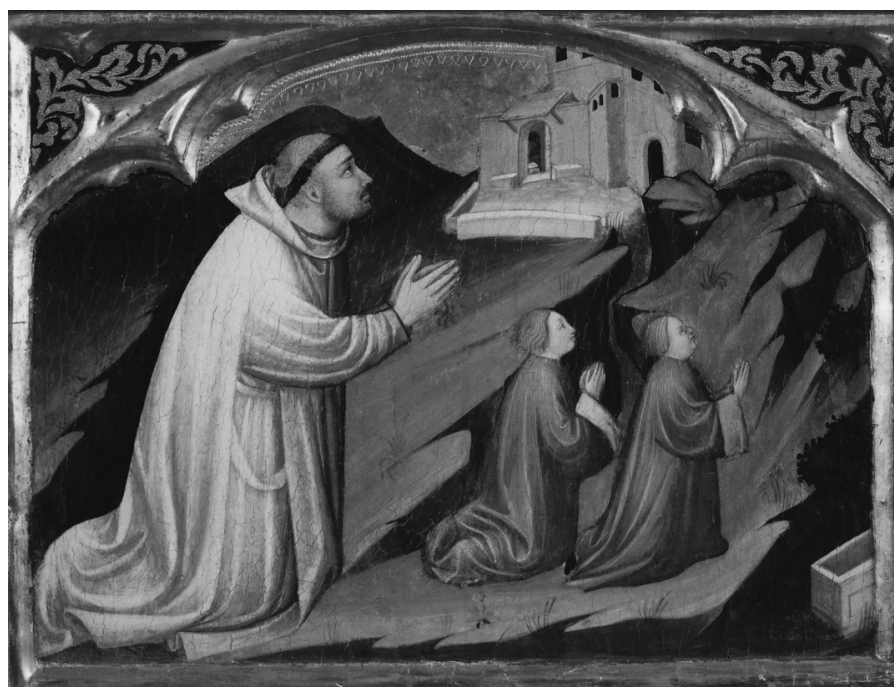

Fig. 1. Bonifacio Ferrer con dos hijos, Gherardo di Jacopo Starnina, ca. 1396, Valencia, Museo de Bellas Artes, predela del retablo de los Sacramentos.

dría de rentas suficientes como para pagar a dicho artista, tal y como se puede desprender de las fuentes que nos hablan de una "gruessa hacienda"9 que repartió "parte en pobres, y en otras obras pias, parte al dicho Monasterio, y parte á sus hijos". ${ }^{10}$ El nuevo religioso cartujo diseñaría la configuración del retablo indicando las escenas que quería que se representaran, ${ }^{11}$ las cuales establecen conexiones con episodios de la vida del venerable. ${ }^{12}$ No obstante, lo que más nos interesa son las dos pequeñas tablas laterales de la prede- la, pues en ellas Bonifacio quiso que le retrataran a él, a su esposa y a nueve de sus hijos, con una curiosa distribución. Así queda recogido en los manuscritos de dicha cartuja: "Al pie del retablo está retratado el sobredicho padre [Bonifacio Ferrer] con los dos hijitos que le quedaban vivos de los 4 que tenía al tiempo de tomar el ábito, y su mujer difunta con 7 hijas todas muertas de poca edad, y en las polseras del retablo se pintaron sus armas, una herradura y tres puentes, porque su mujer se decía Jaumeta Despont, de los bienes de la qual y del dote de su hija Isabel, hizo labrar la capilla, según él dexó escrito de su mano".13

En la tabla del extremo izquierdo (Fig. 1) se representa a fray Bonifacio arrodillado vestido con hábito de cartujo y tonsura, con las manos juntas en posición de oración. Posee algunos rasgos individualizados, ${ }^{14}$ como una barba corta, cosa que es más difícil contemplar en el caso de los hijos que aparecen junto a él. Sobre la identificación de dichos vástagos hay ciertos problemas, puesto que por la documentación conservada se deduce que Bonifacio y Jaumeta tuvieron cuatro hijos varones. Pablo y Lucas eran los mayores y estos habrían fallecido antes de la epidemia que acabó con la vida de su esposa y siete de sus hijas, por lo que todo parece apuntar que estos dos hijos no fueron representados, sino que se pintó a los menores, Juan y Francisco, ${ }^{15}$ los cuales estarían vivos cuando su padre profesó en la orden. No obstante, algunos autores, al observar un sarcófago abierto en la escena donde está Bonifacio, se decantan más por pensar que los hijos pintados serían los difuntos y

FRECHINA, José (dir.), Pintura europea del Museo de Bellas Artes de Valencia. Valencia: Generalitat Valenciana, 2002, pp. 2233; GÓMEZ FRECHINA, José, "Retablo de fray Bonifacio Ferrer". En: BENITO DOMÉNECH, Fernando; GÓMEZ FRECHINA, José, La memoria recobrada, pintura valenciana recuperada de los siglos XIV-XVI. Valencia: Generalitat Valenciana, 2005, pp. 44-46; FUSTER SERRA, Francisco, 2012 (nota 2), pp. 31-73; PALUMBO, Maria, 2015 (nota 6), pp. 356-380.

${ }^{9}$ Bonifacio obtuvo 3.000 libras por la venta del lugar de Alfara. TEIXIDOR, José, "Noticia de Bonifacio, Hermano de San Vicente Ferrer". En: ESPONERA CERDÁN, Alfonso (ed.), 2013 (nota 2), p. 12.

10 Todo esto se conoce por el testamento realizado ante el notario Bernardo Calp el 19 de junio de 1396, pocos días antes de profesar. VIDAL MICÓ, Francisco, 1735 (nota 2), p. 419.

11 MIQUEL JUAN, Matilde, 2008 (nota 7), p. 163; PALUMBO, Maria, 2015 (nota 6), pp. 362-363.

12 AA. VV., La Luz de las Imágenes. Lux Mundi. Xàtiva. Catálogo. Generalitat Valenciana, 2007, p. 303.

13 De Rebus Monasterii Porta-Coeli, s. XVIII (nota 2), p. 101.

${ }^{14}$ Pese a que este hecho ha llevado a algunos autores a considerar que podría haber sido pintado al vivo [GARCíA BORRÁS, Ximo, "El retablo de Fray Bonifacio Ferrer". En: ESPONERA CERDÁN, Alfonso (ed.), 2013 (nota 2), p. 133], no se puede afirmar rigurosamente, puesto que en la época "no es que no exista el retrato pintado, sino que se discurre por unos cauces tradicionales, desde el punto de vista de la concepción del representado. Muy al contrario, se crean imágenes de una sorprendente potencia temática, donde lo que prima es el significado, al margen de la forma en que se traduzcan". (YARZA LUACES, Joaquín, "El retrato medieval: la presencia del donante". El retrato. Barcelona: Galaxia Gutenberg, Círculo de Lectores, 2004, p. 76). No obstante el propio Yarza también señala (p. 62) que "en Italia se plantea por primera vez la figura de facciones veraces en la pintura", citando como ejemplo el retrato de Roberto de Anjou ante su hermano san Luis, una tabla de Simone Martini fechada en 1317.

15 El 2 de junio de 1398 falleció Francisco, que estaba al cuidado de Constanza, fecha que ha servido durante mucho tiempo como límite de la ejecución del retablo. RODRIGO ZARZOSA, Carmen, 1985 (nota 8) p. 30 y TEIXIDOR, José, 2013 (nota 8), p. 13. 
el sarcófago abierto estaba esperando a recibir el cuerpo de Bonifacio para poder reunirse de nuevo con su familia. ${ }^{16}$

Esta escena contrasta con la imagen de la otra parte de la predela, donde aparece Jaumeta Despont con las siete hijas. Todas ellas van vestidas de blanco. Jaumeta, en el extremo derecho, lleva la cabeza cubierta, un collar en el cuello y las manos dispuestas en posición de oración. Respecto a las siete hijas, todas ellas van coronadas de flores y unos haces o rayos de luz emanan de sus figuras. Están ordenadas de forma creciente, de menor a mayor tamaño, teniendo las mayores una coleta o trenza en el pelo y destacando la última de ellas, que sería su hija mayor Isabel, que contaría con doce o trece años en el momento de su fallecimiento, la cual también posee elementos individualizados: un collar, pendientes y sus manos cruzadas sobre el pecho en lugar de estar en posición de oración. Posiblemente se representa de esta manera por tener un papel destacado en la confección del retablo, puesto que el dinero de su dote -hay que suponer que no se casaría por su prematuro fallecimiento- serviría para sufragar dicha obra. ${ }^{17}$ Los signos de las vestiduras blancas, las coronas de flores que aludirían a su virginidad y los rayos de luz muestran que todas esas personas ya se hallaban difuntas en el momento de la confección de la pintura, pero Bonifacio quiso que estuvieran presentes para poder mantenerlas en la memoria, de ahí que la funcionalidad de este retablo fuera un uso privado.

En realidad, el hecho de que Bonifacio apareciera representado en la pintura cuando aún estaba vivo era una práctica muy común en la época: la figura del donante. ${ }^{18}$ Bonifacio se muestra como un donante más, es la persona que ha pagado la obra y por tanto tiene derecho a aparecer en ella, buscando además la salvación de su alma y la de su familia. ${ }^{19}$ Aquí llama la atención que su imagen es de mayor tamaño que la de algunos santos de las escenas contiguas, como san Esteban o san Juan Bautista, pero esto posiblemente sea por adaptarse mejor a las dimensiones de la tabla.
Son muy pocos los retablos valencianos de esta época que han llegado hasta nuestros días, y este además es uno de los más antiguos que se conoce prácticamente entero, aunque por el contrario sabemos que los artistas que abrieron sus primeros talleres en Valencia realizaron una gran cantidad de encargos, la inmensa mayoría hoy desaparecidos. El motivo de su desaparición solía ser el cambio de gusto de las diferentes épocas. Cuando una iglesia se reformaba o remodelaba, se intentaba adaptar la decoración del templo al nuevo estilo imperante y para ello muchas veces los retablos más antiguos, con un estilo más arcaico, eran desmontados y algunas partes reaprovechadas, produciéndose una postergación o desplazamiento a lugares secundarios de los espacios de culto, así como a iglesias o capillas de poca importancia ubicadas en pequeñas aldeas, lo cual en algunos casos ha permitido su conservación y también a veces ha facilitado su desaparición. Esta obra en cambio constituye una excepción. Se sabe que en 1609 se construyó en la iglesia conventual de Portaceli una nueva capilla de la Santa Cruz, donde posiblemente fue trasladado el retablo, la cual en 1625 fue cerrada para ampliar la sacristía. Durante los siglos XVII y XVIII no se puede constatar exactamente dónde estuvo la obra, pero por documentación sabemos que en 1801 permanecía en la iglesia conventual dedicada a San Juan y de hecho tras la exclaustración, en 1847, el retablo figuraba en el catálogo del Museo de Bellas Artes de Valencia procedente de Portaceli. ${ }^{20}$ Es decir, esta obra siempre se conservó en la cartuja para la que fue encargada, y además, posiblemente siempre estuvo en su iglesia, aunque no se descarta que en algunas épocas pudiera haber sido trasladada al claustro o a alguna celda, pero siempre estuvo a la vista de los monjes que nunca se plantearon desmontar sus piezas o cederlas a otro lugar. Únicamente hay que lamentar la pérdida del guardapolvo, donde se sabe que estaban pintadas las armas de Bonifacio y Jaumeta. ${ }^{21}$ Este hecho puede ser simple casualidad, o también se puede apuntar a otro hipotético motivo: la veneración que tenía entre los monjes la figura de fray Bonifacio.

\footnotetext{
16 FUSTER SERRA, Francisco, 2012 (nota 2), pp. 58-59 y GARCíA BORRÁS, Ximo, 2013 (nota 14), p. 134.

17 De Rebus Monasterii Porta-Coeli, s. XVIII (nota 2), p. 101.

${ }_{18}$ Sobre la figura del donante se puede consultar: YARZA LUACES, Joaquín, 2004 (nota 14), pp. 55-89; ALCOY, Rosa, Anticipaciones del Paraíso. El donante y la migración de sentido en el arte del Occidente medieval. Vitoria-Gasteiz: Sans Soleil Ediciones, 2017.

19 "La representación de los donantes ante las figuras sagradas, que son objeto de devoción, no es en ningún caso banal. En realidad, proporciona soluciones gráficas aptas para plantear y difundir la posibilidad de acceso merecido de algunos seres humanos al Paraíso". ALCOY, Rosa, 2017 (nota 18), p. 13.

20 FUSTER SERRA, Francisco, 2012 (nota 2), pp. 36-37.

21 FUSTER SERRA, Francisco, 2012 (nota 2), p. 60.
} 
Bonifacio Ferrer había sido el primer hijo ilustre de dicho monasterio: no solo ilustre en abogacía, teología y letras, sino también en santidad. Por eso en dicho cenobio fue venerado como santo, aunque siempre con la moderación que caracteriza a los cartujos, los cuales nunca se preocuparon por la canonización de los santos de su orden, de ahí que su fundador, san Bruno, pese a vivir en el siglo XI no tuvo un reconocimiento oficial de su culto por parte de la Iglesia hasta 1514. ${ }^{22}$ Otro detalle que se debe apuntar es que fray Bonifacio, aunque había profesado y vivido varios años en Portaceli, sus últimos días los pasó en la cartuja de Valldecrist, donde fue sepultado. Por tanto en Portaceli uno de los pocos vestigios materiales que quedaron como testimonio del paso del venerable por aquella casa fue este retablo, de ahí que tal vez se le otorgara especial veneración, más que por el contenido del mismo, por el comitente que lo había encargado y que se había hecho representar en la predela.

Bonifacio Ferrer también destacó, según la tradición, por realizar la traducción de la Biblia a la lengua valenciana. ${ }^{23}$ Esta ardua tarea fue llevada a cabo por diversos monjes cartujos -citados en el colofón del texto como "altres singulars homens de sciencia"- bajo su supervisión entre los años
1396 y $1402,{ }^{24}$ aunque no se estampó hasta 1478 por Alonso Fernández de Córdoba y Lambert Palmart, ${ }^{25}$ poco después de la introducción de la imprenta en Valencia, siendo así una de las más antiguas traducciones impresas de la Biblia en lengua romance. Pero poco tiempo estaría esta Biblia en circulación ya que hacia 1482 empezaron a condenarse los textos bíblicos no escritos en latín, lo que llevó a la destrucción de esta edición por parte de la Inquisición en $1498 .{ }^{26}$ No obstante parece ser que al menos hasta el siglo XVI este texto siguió circulando. ${ }^{27} \mathrm{El}$ último ejemplar completo que se conoce de esta Biblia se conservaba en la Biblioteca Real de Estocolmo y desapareció en el incendio que se produjo en 1697.28

Por otra parte, se sabe que en 1645 fueron a parar a Juan Bautista Civera (1575-1655), ${ }^{29}$ monje cartujo de Portaceli, las cuatro últimas páginas de dicha edición procedentes del archivo de la catedral valenciana. ${ }^{30}$ Él unió la última de ellas a la Segunda parte de los Annales de la presente casa de Porta-Coeli que estaba escribiendo, ${ }^{31}$ la cual era muy importante, puesto que en su colofón se podía atribuir la autoría de la obra a Bonifacio, y además incorporó en la hoja una estampa del venerable autor de la traducción ${ }^{32}$ (Fig. 2). El manus-

22 De hecho el propio Bonifacio escribió una obra en la que razonaba la ausencia de necesidad por parte de la orden de canonizar a sus monjes: Libellus ostendens quod ad probandam sanctitatem, et puritatem Ordinis cartusiensis non est necessarium quod dictus Ordo habeat sanctos canonizatos, vel quod in cadem Ordine fiant miracula, sicut fit in ceteris Ordinibus approbatis. VILLANUEVA, Joaquín Lorenzo, Viage literario á las Iglesias de España. Madrid: Imprenta Real, 1806, t. 4, pp. 31 y 226-235.

23 Sobre esta obra ver: XIMENO, Vicente, 1747 (nota 2), t. 1, pp. 23-24; HAEBLER, Konrad, "The valencian Bible of 1478". Revue Hispanique, 1909, n² 21, pp. 371-387; GÓMEZ, Ildefonso María, Escritores cartujanos españoles. Barcelona: Publicacions de I'Abadia de Montserrat, 1970, p. 60; VENTURA, Jordi, La Biblia valenciana. Barcelona: Curial edicions catalanes, 1993; IZQUIERDO GIL, Josep, La Biblia en valencià: de la lecció de la sagrada escriptura en llengua vulgar. València: Saó, 1997.

${ }^{24}$ CÁRCEL ORTí, Vicente, Historia de la Iglesia en Valencia. Valencia: Arzobispado de Valencia, 1986, t. 1, p. 134 y NAVARRO SORNÍ, Miguel, "El tiempo de los Borja, Siglo de Oro de la Iglesia valenciana". En: AA. VV., La Luz de las Imágenes. Valencia: Generalitat Valenciana, 1999, vol. 1, p. 147. Otros autores indican que la traducción se realizó entre 1396 y 1400 [FUSTER SERRA, Francisco, 2012 (nota 2), p. 37]; e incluso algunos la retrasan a la etapa posterior al Concilio de Pisa (1410), elaborándose así en la cartuja de Valldecrist [TRAMOYERES BLASCO, Luis, "La Biblia valenciana de Bonifacio Ferrer, una hoja incunable del Apocalipsis". Revista de Archivos, Bibliotecas y Museos, 1909, n²1, pp. 241-242; GÓMEZ GARCÍA, Vito-Tomás, "La figura de Bonifacio Ferrer". En: ESPONERA CERDÁN, Alfonso (ed.), 2013 (nota 2), p. 39].

${ }^{25}$ Sobre estos impresores y la edición de esta obra se puede ver: SERRANO MORALES, José Enrique, Reseña histórica en forma de diccionario de las imprentas que han existido en Valencia desde la introducción del arte tipográfico en España hasta el año 1868 con noticias bio-bibliográficas de los principales impresores. Valencia: Imp. de F. Doménech, 1898-1899 (reed. Valencia: Librerías París-Valencia, 1987), pp. 149 y ss.

${ }^{26}$ Sobre toda la represión inquisitorial de esta traducción bíblica, ver: VENTURA, Jordi, 1993 (nota 23).

27 GÓMEZ, Ildefonso María, 1970 (nota 23), p. 60.

${ }^{28}$ Sobre la existencia de otros fragmentos que tal vez procedan de esta Biblia valenciana, ver: GÓMEZ, Ildefonso María, 1970 (nota 23), p. 60; IZQUIERDO GIL, Josep, 1997 (nota 23), p. 87

29 Sobre este importante clérigo, ver: FERRE DOMÍNGUEZ, Josep-Vicent, 2004 (nota 4).

30 Según apunta Tramoyeres, éstas se las "regaló un clérigo amigo, por ignorar el cartujo la existencia de semejante versión". TRAMOYERES BLASCO, Luis, 1909 (nota 24), p. 243.

31 La primera parte de esta obra en la actualidad está perdida y solo se conserva la segunda, que posiblemente sería la única que pasaría a limpio su autor. FERRE DOMÍNGUEZ, Josep-Vicent, 2004 (nota 4), pp. 29-30.

32 Sobre este folio se puede ver: AA. VV. "Catálogo". En: AA.VV., La Luz de las Imágenes. Alicante. Alicante: Generalitat Valenciana, 2006, pp. 174-176. 
crito de dichos Anales acabó en la Hispanic Society de Nueva York bastante después de la desamortización, en cuya biblioteca hoy en día se conserva con la signatura ms. $n^{\circ} \mathrm{B} 1141 .^{33}$

El elemento que más nos interesa analizar es la estampa, realizada probablemente por el propio padre Civera. ${ }^{34}$ En dicha efigie aparece Bonifacio Ferrer de medio cuerpo, portando en la derecha un libro y en la izquierda un crucifijo, viste hábito de cartujo y muestra la tonsura, guardando el rostro cierta semejanza con la pintura de Starnina. ${ }^{35}$ En la inscripción se le refiere como general de la orden y no se alude a su santidad, pero en cambio en la imagen posee un nimbo, el cual parece que esté borrado o que se intente camuflar con el fondo.

El hecho de incorporar esta imagen tal vez serviría para legitimar la autoría de la traducción bíblica, que aunque estaba ratificada por el colofón, hasta la fecha, según afirmaba el propio Civera, nadie había hablado de la existencia de una Biblia traducida por Bonifacio Ferrer. ${ }^{36}$ Así, aunque algunos autores mantienen esta atribución, los estudios más recientes ${ }^{37}$ consideran que el hermano de san Vicente no tradujo ninguna Biblia al valenciano, " $i$ que el seu nom fou utilitzat per a obtenir l'aprovació eclesiàstica de la publicació i mostrar la bondat de la traducció, que, segurament, d'altra forma, no hagués estat autoritzada, pel fet de ser una traducció del text sagrat a una llengua vulgar". ${ }^{38}$

Tal vez por agudizar más la legitimación de la traducción bíblica, el padre Civera representó a Bonifacio nimbado, como si de un santo se tratara, cosa que demuestra también la estima y veneración

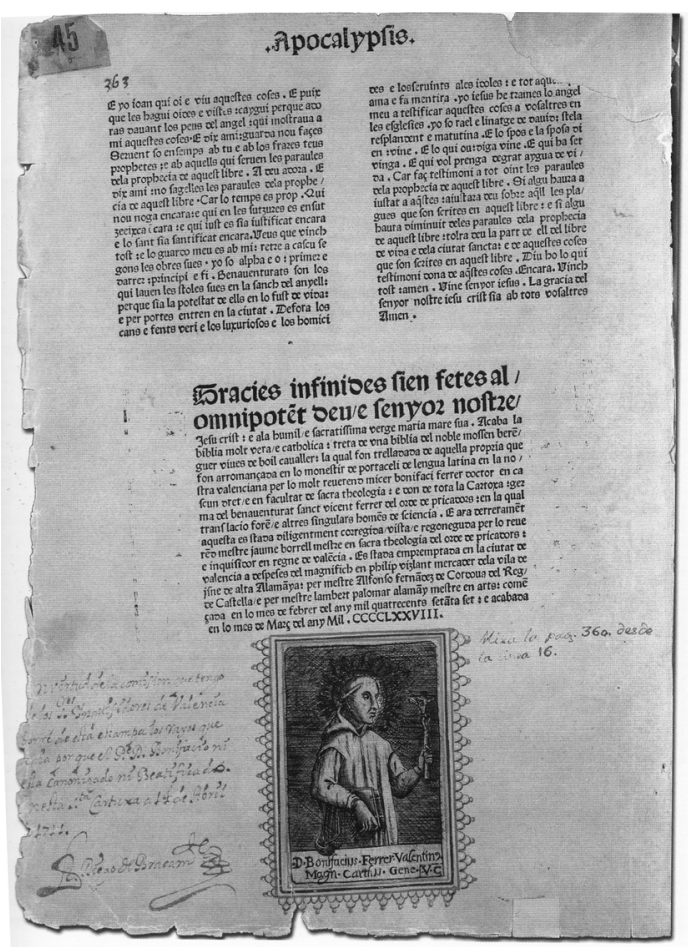

Fig. 2. Última página de la Biblia Valenciana, incluida en los Anales de la Cartuja de Portaceli, Juan Bautista Civera, ca. 1645, New York, Hispanic Society of America, Ms B 1141.

en que se tendría al venerable cartujo por parte de la comunidad de Portaceli y por el propio religioso. ${ }^{39}$ Debido a eso, junto a la estampa aparece la siguiente inscripción marginal: "En virtud de la comision que tengo de los Sres. Inquisidores de Valencia borré de esta estampa los rayos que te-

\footnotetext{
${ }^{33}$ Sobre este manuscrito, sabemos que tras la exclaustración fue a parar, junto con otros escritos procedentes de Portaceli -una Biblia del siglo XIV que, según la tradición, perteneció a Benedicto XIII y donó al cenobio Bonifacio Ferrer (sobre esta ver: PLANAS BADENAS, Josefina, "Una Biblia manuscrita de la cartuja de Portaceli en la Hispanic Society of America". Anuario de Estudios Medievales, 1995, n 25, pp. 287-294) y un Misal de la propia cartuja-, a manos de un labrador de la alquería de Bellver, el cual lo cedió temporalmente a una exposición organizada por Lo Rat Penat en Valencia entre mayo y junio de 1908. El labrador vendió todos estos libros al bibliófilo catalán Salvador Babra, el cual los hizo llegar al librero de Leipzig Karl W. Hiesermann. La destinación final de este material fue New York: la Biblia y los Anales en la biblioteca de la Hispanic Society y el Misal en la Pierpoint Morgan Library [FERRE DOMíNGUEZ, Josep-Vicent, 2004 (nota 4), p. 66-69]. Tramoyeres, en 1909, señala que la destinación final del manuscrito de Civera iba a ser la Biblioteca Nacional de Berlín [TRAMOYERES BLASCO, Luis, 1909 (nota 24), p. 237, nota 2], cosa que parece ser que nunca ocurrió.

34 TRAMOYERES BLASCO, Luis, 1909 (nota 24), p. 248; FERRE DOMÍNGUEZ, Josep-Vicent, 2004 (nota 4), p. 68.

35 Así lo apunta por ejemplo: GARCíA BORRÁs, Ximo, 2013 (nota 14), p. 133.

36 FERRE DOMÍNGUEZ, Josep-Vicent, 2004 (nota 4), p. 70.

37 VENTURA, Jordi, 1993 (nota 23); IZQUIERDO GIL, Josep, 1997 (nota 23) (fundamentalmente las pp. 87-108); CONEJERO DIONÍS-BAYER, Manuel Ángel (ed.), Reescriptura espiritual per al poble. Aproximació a tres traduccions religioses del segle XV al valencià. Valencia: La Luz de las Imágenes, 1999; pp. 93-112.

${ }^{38}$ FERRE DOMÍNGUEZ, Josep-Vicent, 2004 (nota 4), p. 70. Esta tesis la afirma anteriormente de manera parecida: IZQUIERDO GIL, Josep, 1997 (nota 23), p. 95.

39 El padre Civera se identificaba con la frase que se le atribuye al beato Nicolás Factor cuando visitó el cementerio de la cartuja de Portaceli: "quantos estan aqui enterrados que merecieron estar canonizados!" [Segunda parte de los Anales de la cartuja de Portaceli..., ca. 1645, fol. 253; esta página está reproducida en: FERRE DOMínGUEZ, Josep-Vicent, 2004 (nota 4), pp. 156 y 177].
} 
nia porque el Pe. D. Bonifacio ni está Canonizado ni Beatificado. En esta Sta. Cartuxa a 14 de Abril de 1711. D. Diego de Bracamonte".

Este acontecimiento no deja de resultar curioso en una época, el siglo XVIII, en que las imágenes de venerables no canonizados son muy abundantes en estampas y grabados valencianos. Aquí no se optó por eliminar la imagen, es decir, se podía continuar teniendo dicha estampa incorporada a la obra, e incluso un fragmento de la Biblia en lengua romance, en cambio lo que no se podía tolerar era que dicha imagen portara aureola o cualquier otro símbolo que denotase santidad de forma oficial, lo cual sirve para dejar constancia de un cambio de mentalidad. Este grabado constata la existencia de un control sobre las imágenes por parte de la Iglesia en el siglo XVIII, al que algunas obras lograron escapar, pero otras como esta, no.

En los siglos XVII-XVIII encontramos múltiples representaciones de Bonifacio Ferrer, muchas veces puesto en relación con otros venerables cartujos hijos de Portaceli, como Francisco Maresme (13791463), ${ }^{40}$ Francisco Aranda (1346-1438) ${ }^{41}$ y Juan de Nea (†1459)..$^{42}$ En 1640 Ginés Díaz realizó un lienzo de cada uno de ellos para la iglesia conventual pero, seguramente a raíz de la remodelación del templo en las últimas décadas del siglo XVIII, pasaron al claustro de las Murteras, el segundo de los claustros con celdas. ${ }^{43}$ Bonifacio Ferrer (Fig. 3) aparece de cuerpo entero, girado hacia la dere-

40 Oriundo de Sagunto, ingresó en Portaceli en 1402, al acabar sus estudios, y fue elegido prior en 1414, permaneciendo en el cargo diez años. Tuvo fama de limosnero. Intervino en la fundación de la cartuja catalana de Montealegre (1415), de donde también fue prior -de igual manera que en Valldecrist-, y en los años 1418-1419 se le encomendó, junto al entonces prior de Valldecrist, hacer las gestiones oportunas para acabar con el cisma de la Orden. Fue visitador de la provincia de España. Su fama en la cartuja fue aumentando, hasta el punto que el General de la Orden delegó en él y otros priores para el Concilio de Basilea, en 1431, asistiendo a la votación papal, recibiendo en la misma diez votos. Félix V, elegido papa en dicho cónclave, quiso recompensarlo nombrándolo cardenal, pero él rehusó a tal dignidad. En 1437 fue elegido General de la Orden. En ese cargo dio muestra de sus excelentes dotes como administrador. Su biografía está recogida en diversas fuentes y estudios, como por ejemplo: CIVERA, Juan Bautista, Vida del venerable Fray Juan de Nea, profeso de Portaceli y Nuncio Apostólico. Breues apuntamientos de la vida del santo padre D. Francisco Maresme General 28. Ms 723, Montserrat, Biblioteca del Monasterio, Siglo XVII, ff. 17-19v; LE VASSEUR, Leone (nota 2), 1890, vol. 1, pp. 110-112; FERRER ORTS, Albert, "El cartujo Francisco Maresme, un saguntino universal". Braçal: revista del Centre d'Estudis del Camp de Morvedre, 2014, nº 49, pp. 69-94.

${ }^{41}$ Nacido en Teruel, fue un varón muy docto que destacó por su prudencia y piedad. Estuvo al servicio del rey Pedro IV de Aragón y los infantes Juan y Martín, pero le inculparon en 1389 por la muerte del hijo primogénito de Juan I, el infante D. Fernando, de quien era preceptor, y fue encarcelado en Morella. Al subir al trono Martín el Humano fue puesto en libertad para servir a la casa real, pero el 31 de enero de 1398, a los 52 años, decidió tomar el hábito de donado en la cartuja de Portaceli, siendo su maestro de novicios Bonifacio Ferrer. Su vida fue un continuo servicio al rey y a la causa del Papa Luna, participando también como compromisario en Caspe por parte de Aragón. Por orden de Benedicto XIII tuvo que abandonar Portaceli y establecerse con él en Aviñón, donde permaneció varios años. En enero de 1417 se volvió a retirar a Portaceli abandonando al Papa Luna, dirigiéndole una carta en que le recomendaba la sumisión a Martín V. Por su mediación ante el rey y el papa consiguió grandes donaciones y beneficios para Portaceli, a los que añadía importantes aportaciones de su fortuna personal, promoviendo numerosas construcciones. Por su condición de donado no podía residir en los claustros eremíticos ni acudir al coro con los monjes, pero se le hizo la excepción de construirle una celda aparte, comunicada con los claustros, y con acceso a la iglesia junto con los monjes. Falleció a los 92 años en Portaceli. Su biografía está recogida en diversas fuentes y estudios, como por ejemplo: ORTIZ, José Mariano. Compendio de la vida de Don Francisco Fernández Pérez de Aranda, Ayo y Preceptor que fue del Infante D. Fernando, Hijo del Rey D. Juan el I de Aragón: ilustrado con varias noticias históricas... Madrid: Manuel Martín, 1777, pp. 1-36; Leone, LE VASSEUR, Leone (nota 2), 1890, vol. 4, pp. 109-121; FERRER MALLOL, Ma Teresa, "Un aragonés consejero de Juan I y Martín el Humano: Francisco de Aranda". Aragón en la Edad Media, 1999, n 14-15, 1, pp. 531-562; FERRER ORTS, Albert; FERRER DEL RíO, Estefanía, "Francisco de Aranda (1346-1438): noble y cartujo al servicio de la corona de Aragón". Historias del Orbis Terrarum, 2015, n 15, pp. 41-58.

${ }^{42}$ Supuestamente es de origen aragonés. De joven entró al servicio de Fernando I de Aragón. Fue carpintero, y acogió en su casa a Tomás de Sarzana, hijo de un médico de Luca que estudió en Valencia, aunque otras fuentes señalan que ambos fueron simplemente compañeros de estudios. Al quedar viudo, entró en la cartuja y tomó en 1413 el hábito de fraile lego en Portaceli. Era un hombre letrado y buen administrador, que en ausencia de Francisco Aranda dirigió las obras de construcción de la cartuja. Es conocida su buena relación con Francisco Maresme, de hecho, cuando fue elegido prior de Montealegre, Maresme llevó consigo a Juan de Nea para que se encargara de la administración y dirigiera las obras de construcción de la cartuja catalana. Llevó también los negocios de la Gran Cartuja en los reinos de la Corona de Aragón, intervino en la fundación de la Anunciata de Portaceli y la reina María se sirvió de él como embajador ante la Santa Sede y el rey Alfonso, a la sazón en Sicilia. En uno de esos viajes se encontró con su antiguo amigo Tomás de Sarzana, que había sido elegido papa como Nicolás V, el cual le nombró Colector General de la Cámara Apostólica y de la Cruzada en los reinos de la Corona de Aragón, cuyas rentas servirían para la construcción de la cartuja de Montealegre. En 1448 volvió de Roma, iniciando la mejora de la obra de Montealegre, donde acabaría falleciendo. Su biografía está recogida en diversas fuentes, como por ejemplo: CIVERA, Juan Bautista (nota 40), ff. 1-16v; VALLES, José de, Primer Instituto de la Sagrada Religión de la Cartuxa. Fundaciones de los conventos de toda España, martires de Inglaterra, y generales de toda la Orden... Barcelona: Mateo Barceló, 1792, pp. 185-186; LE VASSEUR, Leone (nota 2), 1890, vol. 4, pp. 10-13.

${ }^{43}$ FUSTER SERRA, Francisco, 2012 (nota 2), pp. 400 y 424. 
cha, portando hábito cartujo, mostrándose su tonsura y una ligera barba como la que se puede apreciar en el retrato de Starnina. Esta imagen del rostro barbado, que ya utilizó el artista italiano, será la más repetida del venerable, por ser así como está pintado en la única imagen que se conoce realizada en vida, aunque en algunas ocasiones se le representa imberbe. La mano izquierda la tiene sobre el pecho y con la derecha sostiene un libro cerrado que podría aludir a alguna obra que escribió el propio Bonifacio aunque posiblemente sean los estatutos de la Cartuja, elemento que porta por haber sido General de la Orden ${ }^{44}$ y que se puede apreciar también en la obra de la serie que representa a Francisco Maresme, el otro religioso del monasterio que ocupó el mismo cargo. A la parte derecha de la pintura, en el suelo, hay un capelo cardenalicio y una mitra. Estas dignidades no aparecen citadas en las fuentes biográficas que conocemos actualmente del venerable, no obstante aludirían a cargos concretos que él rechazaría. Bonifacio Ferrer, de igual manera que su hermano san Vicente, mantuvieron una relación muy estrecha con el papa Benedicto XIII, actuando como nuncios en diferentes ocasiones e incluso acudiendo a concilios. El mismo papa Luna fue quien obligó a Bonifacio a aceptar el cargo de General de la Orden de la Cartuja, el cual él quiso rechazar. No sería así de extrañar que, de igual manera que a su santo hermano, el papa le ofreciera a Bonifacio otras dignidades eclesiásticas a las cuales renunciaría, o que la tradición creyera que se las había ofrecido, de ahí que aparezcan estos elementos en el suelo. Por último a la parte izquierda, sobre una mesa cubierta de una tela púrpura, hay una corona, la cual hace clara alusión a la participación de fray Bonifacio en el Compromiso de Caspe para la designación del nuevo monarca de la Corona de Aragón en 1412. ${ }^{45}$

El traslado de estos lienzos al claustro de las Murteras posiblemente responda más a motivos estéticos que a motivos devocionales, puesto que en 1774 se documenta a José Camarón realizando unas pinturas para el testero de la iglesia, ${ }^{46}$ enfrentado con el retablo mayor, conservadas in situ, donde se representó en una imagen central a la Virgen amparan-

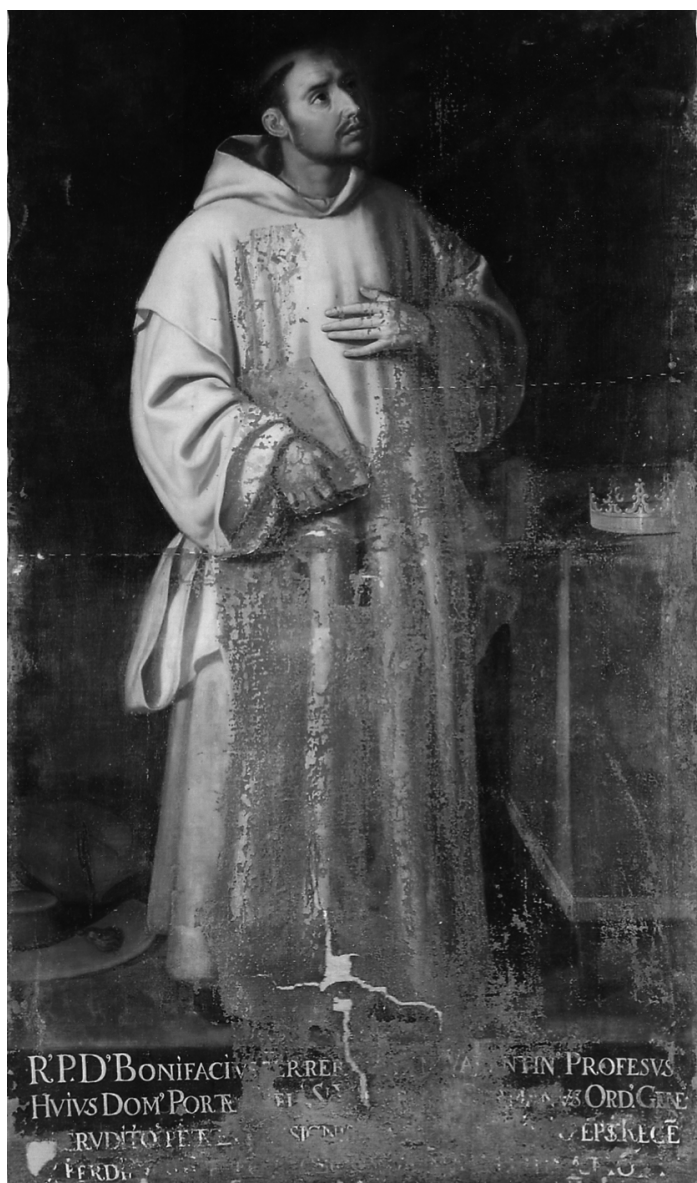

Fig. 3. Bonifacio Ferrer, Ginés Díaz, 1640, Valencia, Museo de Bellas Artes.

do bajo su manto a los cartujos y a los lados se pintaron de nuevo a estos cuatro ilustres religiosos. Para la realización de estas obras Camarón se inspiró en los atributos y rostros de los lienzos de Ginés Díaz, aunque en esta ocasión las pinturas son de medio cuerpo y suele haber una mesa junto a ellos donde se depositan sus atributos. Así Bonifacio Ferrer aparece de nuevo portando los estatutos, con corona y capelo cardenalicio. ${ }^{47}$

Además de estas obras individuales, conocemos varios grabados donde se representa a la Virgen

\footnotetext{
44 FUSTER SERRA, Francisco, 2012 (nota 2), p. 426.

45 En la parte inferior, por si hubiera alguna duda sobre su identificación, se puso una inscripción, hoy en día muy mal conservada, en la que se puede leer: "R' P. D' BONIFACIVS FERRER (...) VALENTIN' PROFESUS / HVIVS DOM' PORTAE (COELI) S' V (...) LANVS ORD'. GENEI (...) ERVDITIO PETA (..) SIGNVM (...) EPS RECE / (..) FERDI (...)". FUSTER SERRA, Francisco, 2012 (nota 2), p. 426.

46 FUSTER SERRA, Francisco, 2012 (nota 2), p. 487.

47 ESPINÓS DÍAZ, Adela, José Camarón Bonanat. 1731-1803, Exposición en el Museo de Bellas Artes de Castellón, Octubre 2005 - Enero 2006. Generalitat Valenciana, 2005, pp. 76-77.
} 


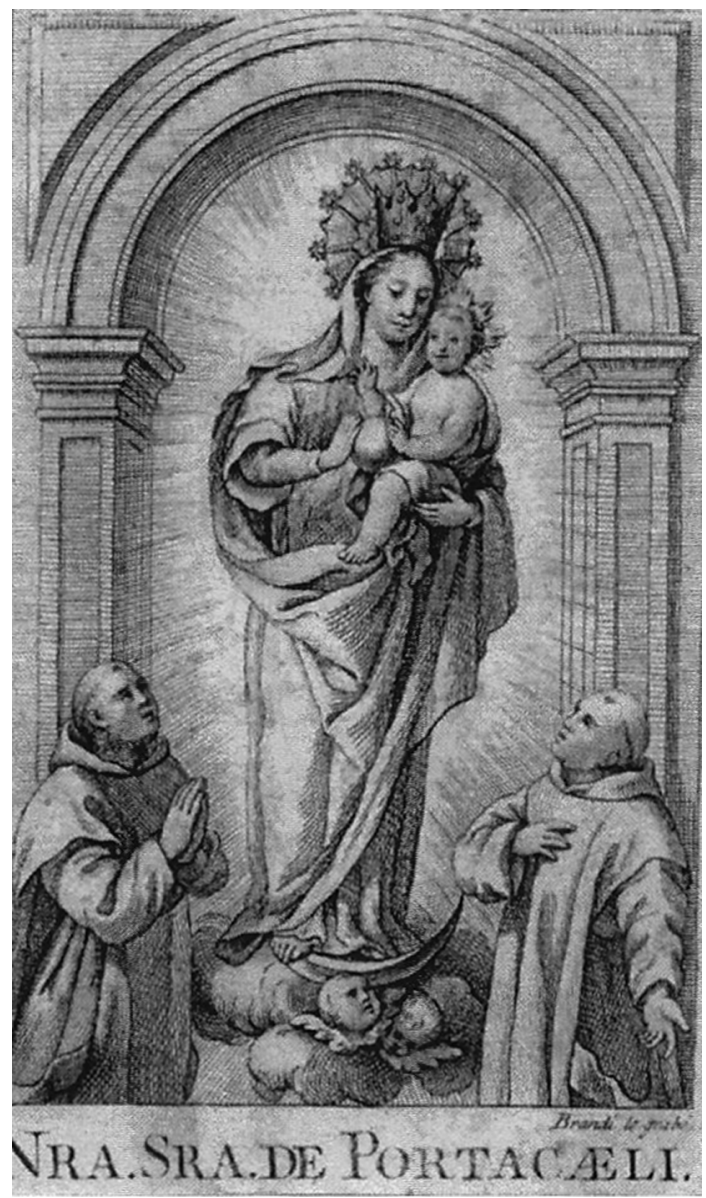

Fig. 4. Virgen de Portaceli con Bonifacio Ferrer y Francisco Maresme, Mariano Brandi, s. XVIII, Valencia, Museo de Bellas Artes.

de Portaceli y en algunos de ellos podemos contemplar a religiosos cartujos a su lado. Tal es el caso de una estampa de Mariano Brandi (activo entre 1779 y 1824) (Fig. 4) en la que aparece la Virgen dentro de una puerta (Porta Coeli) y a su lado dos monjes cartujos, el de la izquierda con las manos puestas en oración y el de la derecha se lleva la mano diestra al pecho y extiende la zurda. De la misma manera, en otro grabado anónimo similar fechado en los siglos XVIII-XIX vuelve a aparecer la Virgen junto a estos dos cartujos, y por detrás de cada uno aparecen dos grupos de dos y tres cartujos respectivamente. En este caso las posiciones de los religiosos que encabezan los grupos están invertidas, pero sus rostros y gestos son idénticos a los de la anterior estampa. En ninguno de estos casos los monjes que figuran a los pies se representan con un nimbo o algún elemento que les pueda aludir como santos, por lo que no sería plausible pensar que pudieran ser san Bruno y san Hugo, los santos de la orden por excelencia; serían religiosos de dicha cartuja, la de Portaceli. Podríamos no ir más allá y pensar que son monjes anónimos, pero considero que hay motivos para creer que esto no es así.

Cuando Juan Bautista Civera escribió la Segunda parte de los Anales de la cartuja de Portaceli, hacia 1645, entre las páginas 28 y 29 intercaló una lámina donde se representaban a los religiosos sobre los que hablaba en dicha obra. ${ }^{48}$ La disposición de estos cartujos es a modo de árbol, de manera que hay un tronco central en cuyo centro, a los pies, está la Virgen de Portaceli, inserta en la puerta (Porta Coeli), y a partir de aquí surgen ramas y sobre las hojas de las mismas se van apoyando pequeños retratos de medio cuerpo de los diferentes monjes identificados siempre con una inscripción, escrita en una filacteria que suelen sostener en la mano. Los religiosos se disponen de manera simétrica, repitiendo composiciones, y parecen estar interactuando entre ellos. En la parte superior los cartujos no portan la filacteria, sino que el nombre viene escrito en la hoja donde se apoyan, perdiéndose una gran multitud de monjes que se mezclan con un rompimiento de gloria donde aparece la Trinidad. Por diferentes zonas del dibujo se ven cartelas con inscripciones y ángeles. Pero esta colocación de los cartujos no parece ser banal. Los que se disponen en la parte más baja son representados de mayor tamaño, incluso con ciertos rasgos personalizados, mientras que a medida que se va escalando los religiosos tienen menores dimensiones hasta que en la parte superior ya ni siquiera se distinguen, confundiéndose con las nubes. En la parte inferior, donde se reserva el espacio para los más importantes, aparecen a la derecha de la Virgen Bonifacio Ferrer, de tres cuartos, y a su izquierda Francisco Maresme, de perfil. A la izquierda de Bonifacio, y en un plano ligeramente superior, está Juan de Nea caracterizado por su larga barba, y a la derecha de Maresme aparece Francisco Aranda también de perfil (Fig. 5).

Si comparamos esta imagen con las pinturas dispuestas en el testero de la iglesia conventual, realizadas por José Camarón en 1774, nos damos cuenta de que la disposición de las figuras respecto a la Virgen es la misma: en la parte baja Bonifacio a la

${ }^{48}$ La biografía de algunos de estos ilustres cartujos aparece recogida, de manera resumida, en FUSTER SERRA, Francisco, 2003 (nota 2), pp. 219-224. 
izquierda y Maresme a la derecha, y sobre ellos Nea y Aranda respectivamente. De esta manera, volviendo a los grabados iniciales, en la obra de Brandi más que probablemente los religiosos que se disponen a los pies de la Virgen son Bonifacio Ferrer y Francisco Maresme, porque era habitual en el cenobio representarlos a los pies de la Virgen. Ante la dificultad de saber quién es quién, siguiendo las anteriores disposiciones, el de la izquierda debería ser Bonifacio y el de la derecha Maresme. Además, estos están dispuestos de tres cuartos y de perfil respectivamente, tal y como figuraban en el dibujo de los Anales. También en esta misma obra literaria, en la portada de la primera y de la segunda parte, ${ }^{49}$ figura una puerta flanqueada por dos pares de columnas corintias sobre elevados basamentos en los que se apoyan las figuras de estos dos mismos venerables cartujos de cuerpo entero, también en la misma disposición aunque ambos de tres cuartos, teniendo Bonifacio a sus pies una mitra y un capelo, y Maresme solo un capelo, sosteniendo un libro abierto en sus manos.

No obstante, en el otro grabado anónimo de los siglos XVIII-XIX que se conserva, la colocación de estos dos religiosos está invertida, no sabemos exactamente por qué. Los otros monjes que aparecen por detrás, viendo el número que son y que carecen de rasgos identificativos, posiblemente sí que representen a cartujos anónimos. Pese al cambio de posición, seguimos creyendo que el que aparece de perfil es Maresme y el de tres cuartos Bonifacio. ${ }^{50}$

Esta misma composición de dos religiosos cartujos, uno de perfil y otro de tres cuartos, a los pies de una imagen devocional, había aparecido ya en una obra anterior de Portaceli, en concreto en la Trinidad realizada por Abdón Castañeda, hoy conservada en el Museo de Bellas Artes de Valencia, fechada en 1631 (Fig. 6), que fue encargada precisamente por el padre Juan Bautista Civera. ${ }^{51}$ En ella aparece la Trinidad en el centro y a los pies, a la izquierda un cartujo de perfil y a la derecha otro de tres cuartos. Observando la figura de perfil, y comparándola con el dibujo de los Anales,

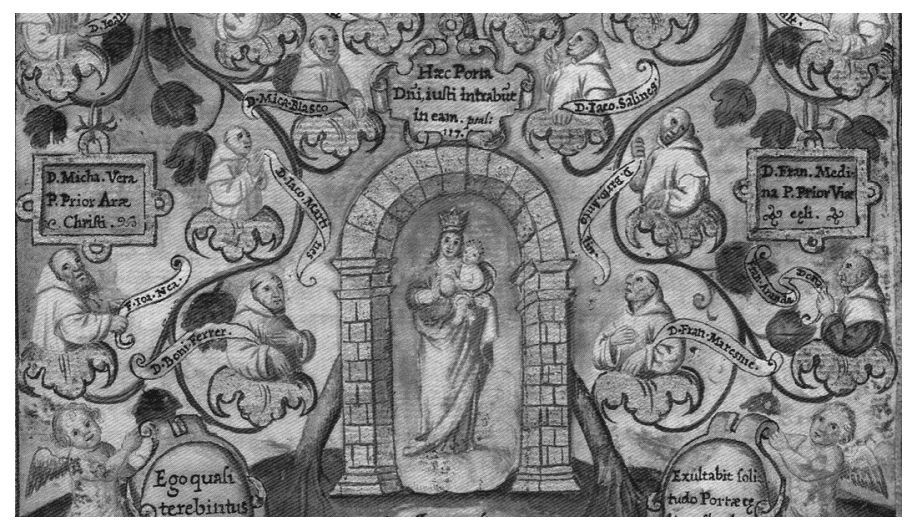

Fig. 5. Arbol de los religiosos de quien se escribe en los Anales de la Cartuja de Portaceli (detalle), Juan Bautista Civera, ca. 1645, New York, Hispanic Society of America, Ms B 1141, entre las pp. 28-29.

nos damos cuenta de que es muy similar a la que Civera identifica como Francisco Maresme, con el rostro elevado hacia arriba, de perfil, la boca entreabierta y la nariz aguileña. De la misma manera también resulta muy semejante la imagen de Bonifacio que aparece al otro lado de la pintura de Castañeda. Lo único que cambia, en ambos casos, es la disposición de las manos. De esta forma, se refuerza más todavía la teoría de que aquél que aparece de perfil es Maresme y el de tres cuartos es Bonifacio, independientemente de la posición que ocupen en la obra. Además, el cartujo de la derecha está representado con nimbo. De todos los hijos de Portaceli, el más ilustre de todos y el que más fama de santidad tuvo fue el hermano de san Vicente. Como ya se ha indicado anteriormente, existían imágenes de Bonifacio Ferrer con nimbo, como la que probablemente realizó el padre Civera para la última página de la Biblia valenciana. Los venerables no canonizados a veces eran representados con atributos de santidad como nimbos, ${ }^{52}$ algo que fue prohibido definitivamente mediante los decretos Non Cultu de Urbano VIII. Estos

\footnotetext{
49 FUSTER SERRA, Francisco, 2003 (nota 2), p. 274; FUSTER SERRA, Francisco, 2012 (nota 2), p. 465.

${ }^{50}$ Esta teoría de considerar al que está retratado de perfil a Maresme y al que está de tres cuartos Bonifacio, tiene como especial fundamento el dibujo de los Anales de Civera, donde aparecen identificados con filacterias como tal. No obstante la principal objeción que se puede poner a esto es que en las imágenes del siglo XV que conservamos de ambos venerables, realizadas en vida, Bonifacio se representa de perfil y Maresme de tres cuartos. La obra que conocemos de este último es el guardapolvo del Retablo de los Martí de Torres, Gonçal Peris, ca. 1449, Valencia, Museo de Bellas Artes, cuya identificación apunta FUSTER SERRA, Francisco, 2012 (nota 2), p. 145.

${ }^{51}$ FUSTER SERRA, Francisco, 2012 (nota 2), pp. 393-395.

52 Así lo observamos también en el caso de otros venerables valencianos como Francisco Salelles ( $\$ 1310)$, Juan Gilabert Jofré (1350-1417) o Francisco Jerónimo Simón (1578-1612).
} 


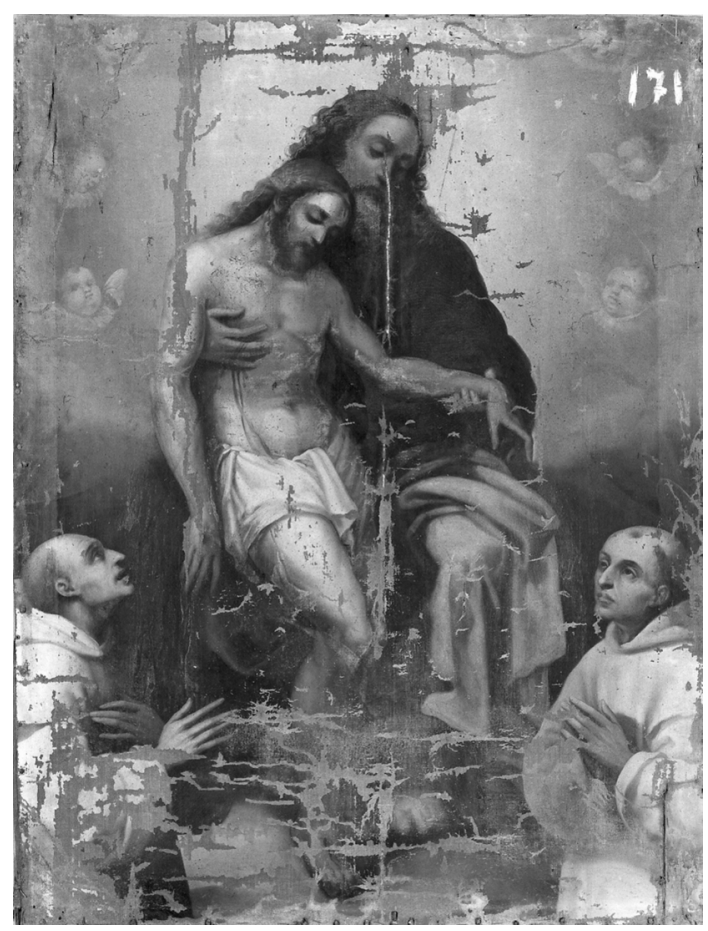

Fig. 6. Trinidad con Francisco Maresme y Bonifacio Ferrer, Abdón Castañeda, 1631, Valencia, Museo de Bellas Artes.

fueron varios, expidiéndose el último en 1634, ${ }^{53}$ mientras que esta pintura se fecha en 1631, por lo que todavía no estaría en vigor dicha prohibición o aún no se habría extendido por la región valenciana, lo cual permitió a Civera determinar que el ilustre hijo de Portaceli fuera mostrado como un santo, porque así lo consideraba.

En otro grabado, realizado en época más tardía, hacia 1820, dibujado por Vicente López y grabado por Vicente Capilla, ${ }^{54}$ se representa a la Virgen de Portaceli, a los pies de la cual figuran una serie de santos de la orden. En primer plano están san Bruno y santa Rosalina de Vilanova, tal y como se refleja en la inscripción inferior. Por detrás del santo fundador hay dos obispos nimbados, probablemente san Hugo de Lincoln y san Antelmo de Belley. Y por detrás de santa Rosalina aparecen tres cartujos sin ningún atributo. Estos están dispuestos dos delante y uno detrás. Los dos delanteros figuran uno de perfil y otro de tres cuartos, resultando muy similares sus efigies a las de la pintura de Castañeda, determinando así que son Maresme y Bonifacio. El tercero resulta fácilmente reconocible por su larga barba: Juan de Nea. De esta manera, aquí el grupo de religiosos ilustres de Portaceli se ve ampliado con la presencia de este último.

Pero en algunas otras obras la representación de religiosos cartujos se vio multiplicada, es el caso de la obra de Ginés Díaz del siglo XVII, procedente de la cartuja de Portaceli y hoy en el Museo de Bellas Artes de Valencia, que lleva por título Aparición de la Trinidad y la Virgen a unos cartujos. En esta pintura están en el centro la Virgen acompañada de san José y san Juan Bautista, apareciendo sobre ellos, en un rompimiento celestial, la Trinidad. La Virgen pone sus manos sobre la cabeza de dos religiosos, a la izquierda uno dispuesto de perfil (Francisco Maresme) y a la derecha uno de tres cuartos (Bonifacio Ferrer). Junto a ellos figura un nutrido grupo de monjes, pudiendo distinguir a Juan de Nea, por su larga barba, como el tercero del grupo de la derecha. Tal vez el que lo precede, o algún otro religioso del grupo de la izquierda, sería Francisco Aranda, pero resulta complicado lanzar una propuesta firme. Los cartujos representados seguramente serían o aludirían a los recogidos por Civera en el dibujo y el texto de los Anales, pero es difícil poder establecer paralelismos.

\section{La ciudad de Valencia}

La ciudad de Valencia, localidad natal del venerable cartujo, fue otro foco de culto de Bonifacio, aunque menos relevante. En primer lugar sabemos que se le tuvo cierta veneración en la parroquia en la que fue bautizado: San Esteban. Dicha iglesia quiso siempre recordar a aquellos hijos ilustres que habían tenido el honor de haber recibido el sacramento de iniciación en la misma pila que san Vicente Ferrer. Todavía hoy en día se conserva allí un lienzo que representa a fray Bonifacio Ferrer (Fig. 7) con una inscripción a los pies, casi inapreciable, que reza: "DN. BONIFASIO FERRER GENERAL DE LA CARTUIA, BAUTISADO EN LA PAROCHIA DEL PROTOMARTIR / SN ESTEVAN, EN LA PILA DE SU HERMANO SN VISENTE FERRER. / FUE JURADO DE VALENCIA [EN EL AÑO] DE 1388. PIN[TO]SE EN EL AÑO $1680 "{ }^{55}$ Este texto fecha la obra en 1680 y aunque su autoría es anónima, algunos apuntan a la mano de Domingo Saura. ${ }^{56}$ Una de las primeras referencias documentales de esta pintura nos la aporta Jo-

\footnotetext{
53 Sobre los decretos de Non Cultu de Urbano VIII, ver: FELICI CASTELL, Andrés, 2016 (nota 1), pp. 43-52.

${ }^{54}$ FUSTER SERRA, Francisco, 2012 (nota 2), p. 515.

${ }^{55}$ AA.VV. "Iglesia de San Esteban Protomártir. Catálogo". En: La Luz de las Imágenes. La Gloria del Barroco. Valencia: Generalitat Valenciana, 2009, p. 232.

${ }^{56}$ AA.VV. "Iglesia de San Esteban Protomártir. Catálogo", 2009 (nota 38), p. 233.
} 
sé Rodríguez (1630-1703) pocos años después de su realización, el cual, cuando escribe sobre fray Bonifacio, indica que "su Efigie está, en la Parroquial de San Estevan, de nuestra Patria, con la de su Hermano, S. Vicente Ferrer, por ser bautizados en ella". ${ }^{57}$ En el lienzo aparece Bonifacio vestido con hábito cartujo, tonsura y un ligero bigote, mirando hacia el cielo, con su mano derecha sobre el pecho y la izquierda extendida hacia delante, rodeándose de una serie de elementos que permiten identificarlo. A la parte derecha, en el ángulo inferior, está el escudo de la familia Ferrer con una herradura sobre un fondo blanco y negro. Por encima de este hay una mitra y un capelo cardenalicio, atributos que ya hemos visto representados en la obra de Ginés Díaz para la cartuja de Portaceli. Por encima de estos objetos se vislumbra una construcción arquitectónica entre el paisaje montañoso, que sería o la cartuja de Portaceli, monasterio donde profesó, o la de Valldecrist, donde falleció.

Por otra parte, en el lado izquierdo de la pintura hay un total de cinco libros, uno de ellos abierto en el suelo sobre una calavera, elemento que alude a la mortificación que se vive en la orden cartuja y que es característico de san Bruno, y los otros cuatro aparecen cerrados sobre una piedra y en el lomo está escrito su título. En el primero, de menor formato que los demás, parece leerse "IN TVTA" y no sabemos a qué obra puede referirse. En segundo lugar indica "F. SCHISTA. PISSATA", título que haría referencia a De Schismate Pisano, escrito por Bonifacio Ferrer en 1411, un libro manuscrito que se conservaba en Portaceli, el cual "contiene una muy docta Apologia en respuesta de un memorial en que le culparon, que huviesse obedecido al nombrado Papa Benedicto, quando le mandó reassumir el Generalato, que avia renunciado espontaneamente. $Y$ tambien le escrivió para atraer á la obediencia del mismo Benedicto (á quien entonces juzgava legitimo Pontifice) á muchos de sus Cartuxos, que se avia apartado de ella". ${ }^{58}$ La tercera obra indica en su lomo " $A D^{\circ}$. $B I$ $B^{\prime}$. SACRES", que parece aludir a la traducción de la Biblia al valenciano, de la cual ya se ha hablado anteriormente, obra que en 1680 probablemente ya no se conservaría, excepto algún fragmento como la página recogida por el padre Civera en Portaceli. El último libro parece indicar en su lomo

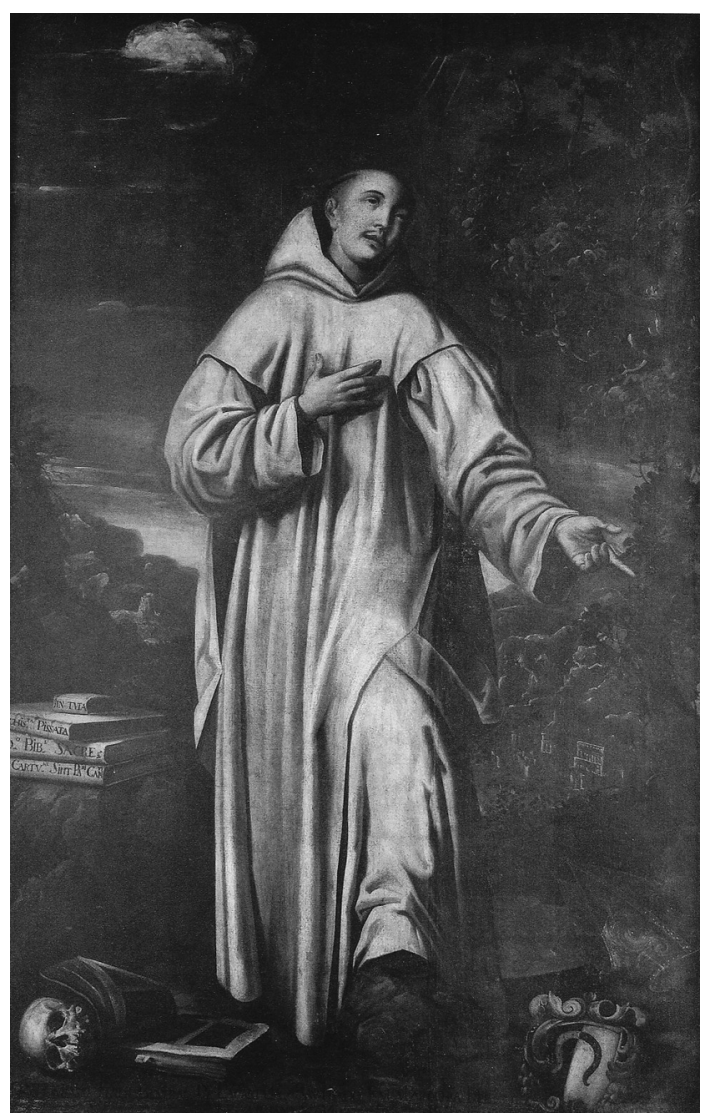

Fig. 7. Bonifacio Ferrer, atr. Domingo Saura, 1680, Valencia, iglesia de San Esteban.

"V. R. CARTVME. SINT PA ST CAN"T", y posiblemente haga alusión a Libellus ostendens quod ad probandam sanctitatem, et puritatem Ordinis cartusiensis non est necessarium quod dictus Ordo habeat sanctos canonizatos, vel quod in cadem Ordine fiant miracula, sicut fit in ceteris Ordinibus approbatis. ${ }^{59}$ El libro que está abierto en el suelo tampoco podemos saber con exactitud a cuál puede corresponder, pudiendo ser algún otro escrito por el venerable o los estatutos de la Cartuja, atributo que caracteriza a los Generales de la Orden y con los que fue representado años antes en Portaceli.

La parroquia de San Esteban siempre se sintió muy orgullosa de todos aquellos venerables hijos

57 RODRÍGUEZ, José, 1747 (nota 2), p. 91.

${ }^{58}$ XIMENO, Vicente, 1747 (nota 2), t. 1, p. 22. Sobre esta obra también se puede consultar: GÓMEZ, Ildefonso María. 1970 (nota 23), pp. 60-61.

${ }^{59}$ Esta obra es referida por Joaquín Villanueva [VILLANUEVA, Joaquín Lorenzo, 1806 (nota 22), t. 4, p. 31] como De miraculis, et Sanctis in Cartusia, pero cuando transcribe su contenido en el apéndice (pp. 226-235), desarrolla el título tal y como se ha recogido en el texto. Sobre este libro también se puede ver: GÓMEZ, Ildefonso María, 1970 (nota 23), p. 61. 
de su pila bautismal, ${ }^{60}$ y muestra de ello es lo acontecido en 1738, para la celebración del quinto centenario de la conquista cristiana de Valencia: "Aunque no avia de passar por su Templo la solemne Procession, adornó las paredes de la Iglesia por lo exterior, vistiendolas de ricos tapices, sobre los quales, y su Puerta principal, que sale á la Plazuela, colocó debaxo de un dosel de terciopelo carmesí la Imagen de su Titular San Estevan, y a sus lados las efigies de los hijos de su Sacra Pila". ${ }^{61}$ Cuando se refieren estos santos hijos que estaban retratados, un total de once, en primer lugar se cita a los dominicos san Vicente Ferrer (1350-1419) y san Luis Bertrán (1526-1581) y al franciscano Nicolás Factor (1520-1583), cuya causa se hallaba muy avanzada en Roma -fue beatificado en 1786-. A continuación aparecen toda una serie de venerables: el cartujo Bonifacio Ferrer (1355-1417), los trinitarios Francisco Davón (†1597) y Marco Antonio Alós (1597-1667), el franciscano Vicente Orient (1623-1677), el capuchino Gonzalo de Ixar (Tomás de Valencia) (1557-1622), el prelado Luis Crespí de Borja (1607-1663), el prelado dominico Acacio March de Velasco (1585-1665) y el virrey de Cerdeña Juan Vives de Cañamás (s. XVI). "Todos estos Retratos estaban alumbrados con gran multitud de antorchas, varias hogueras en la Plazuela á trechos, y copiosissima cantidad de faroles, y globos, de que se coronaron todo el texado de el Templo, y Torre de las Campanas, cuyo regocijo le acompañavan diferentes Geroglificos, y Poesias al assumpto".62

En el año 1745, ante la renovación de la capilla de la Virgen de las Virtudes y del cementerio parroquial de San Esteban, Francisco Mira predicó un solemne sermón donde habló de los venerables hijos de esta pila, y entre ellos, además de los citados, añadió al trinitario Miguel de Contreras ( $\uparrow 1505)$, al jesuita Francisco Escrivá (ss. XVI-XVII) y al dominico Vicente Vitor (1623-1696). ${ }^{63}$ Pocos años después, en 1755, se celebraron también solemnes fiestas para conmemorar el tercer siglo de la canonización de san Vicente Ferrer. En el libro que recogía dichas celebraciones se incluyeron los sonetos expuestos en la plazuela de San Esteban, que "estaban junto á los retratos de los Varones ilustres en Santidad, bautizados en dicha Parroquial". ${ }^{64}$ En esta relación de venerables, encabezada de nuevo por los tres reconocidos oficialmente, respecto a las fiestas de 1738, al único que no se cita es al trinitario Francisco Davón, pero en cambio aparecen cuatro nuevos retratos: el dominico Vicente Vitor (1623-1696), la carmelita descalza Esperanza de Cristo (1671-1746), la agustina descalza Vicenta del Corazón de Jesús (1714-1751) y el jesuita Francisco Escrivá (ss. XVI$\mathrm{XVII})$, completando esta vez un total de catorce retratos acompañados cada uno de un soneto..$^{65}$

Sobre el retrato de Bonifacio Ferrer que se expuso en la plazuela de San Esteban en las celebraciones de 1738 y 1755, no podemos saber con seguridad si era el mismo lienzo pintado en 1680 o era otro realizado ex profeso para la celebración de la conquista de Valencia. De la misma manera resulta complicado saber cuándo se realizaron los demás retratos de la serie. Probablemente fueron encargados para la primera celebración, la de 1738, y para la de 1755 se amplió el conjunto incorporando a los venerables fallecidos en ese lapso de tiempo y los olvidos que se habían tenido en la primera serie, señalados por Francisco Mira en 1745. Sobre qué ocurrió con estas obras después de las celebraciones, apenas hemos encontrado documentación al respecto. En 1912, Francisco de

${ }^{60}$ Debido a la gran cantidad de gente que solicitaba ser bautizada en dicha pila, se tuvieron que tomar medidas limitando el sacramento de iniciación únicamente a los nacidos en la demarcación parroquial. ORELLANA, Marcos Antonio, Valencia Antigua y Moderna. Valencia: Acción Bibliográfica Valenciana, 1923, t. 1, p. 651.

${ }^{61}$ ORTÍ Y MAYOR, José Vicente, Fiestas Centenarias, con que la Insigne, Noble, Leal, y Coronada Ciudad de Valencia celebró en el dia 9 de Octubre de 1738. La quinta centuria de su Christiana Conquista. Valencia: Antonio Bordazar, 1740, pp. 235-236.

62 ORTí Y MAYOR, José Vicente, 1740 (nota 61), p. 237.

${ }_{63}$ MIRA, Francisco, Sermon que a la reedificacion de la Capilla de la Virgen de las Virtudes (fundación del Cid) e Iglesia Parroquial que fue del mismo territorio que oy es de San Estevan, de esta ciudad de Valencia, y a la renovacion de su cementerio, en fiesta que hizo la Muy llustre Parroquia en el dia 29 de agosto de el presente año 1745. Valencia: José Tomás Lucas, 1745, pp. 17-21.

${ }^{64}$ SERRANO, Tomás, Fiestas seculares, con que la coronada ciudad de Valencia celebró el feliz cumplimiento del tercer siglo de la canonización de su esclarecido hijo, y ángel protector S. Vicente Ferrer, Apostol de Europa. Valencia: viuda de José de Orga, 1762, p. 142.

${ }^{65}$ El soneto dedicado a Bonifacio Ferrer, realizado por el padre Antonio Eiximeno, fue el siguiente: "Este del yermo honor, ciprès lozano, / por Vicente al poblado es oy venido / de su espíritu Hijo esclarecido / si de su clara sangre noble hermano. / Mayoral del Rebaño Cartusiano, / mas de su santo exemplo conducido, / que del cayado. O! nunca del olvido / se le atreva la embidia sino en vano. / Vivirà en los poblados su memoria, / si su suerte buscò en las soledades, / memoria, que hilarà mi estilo rudo. / A esta Pila daràn doblada gloria, / gloria, que no marchiten las edades, / clarin Vicente, y Bonifacio mudo". SERRANO, Tomás, 1762 (nota 64), p. 28 
Paula Vilanova, al escribir sobre Juan Vives de Cañamás, señala que "existe su retrato, junto con el de otros Venerables, en la sacristía de la iglesia parroquial de San Esteban". ${ }^{66}$ Este retrato y el de los "otros venerables" posiblemente serían los expuestos en estas fiestas, por eso mismo es plausible pensar que estas pinturas, tras exhibirse en las celebraciones, fueron retiradas a la sacristía de la iglesia, puesto que al no estar los venerables reconocidos oficialmente por la Iglesia no podían exhibirse sus imágenes en lugares públicos del templo. Sobre si se conservaban todos en 1912 o solo algunos no lo podemos saber, como tampoco qué ocurrió con ellos durante la Guerra Civil.

También en menor medida la orden dominica, y especialmente el convento de Predicadores, quiso inmortalizar la figura del venerable hermano del gran santo de la orden, de ahí que su imagen aparezca en algunas obras. La única que se conserva hoy en día es el fresco del cascarón del ábside de la capilla de San Vicente Ferrer, pintado por José Vergara en 1781, y donde en el lado del Evangelio aparece un grupo de personajes históricos relacionados con la vida de san Vicente y la fundación del convento de Predicadores, entre los cuales están Jaime I, Fernando de Antequera y el propio Bonifacio Ferrer, muy fácilmente identificable por su hábito de cartujo, junto al cual aparecen dos obispos. Algunos autores identifican a estos como Andrés Albalat y Alfonso de Borja, ${ }^{67}$ pero teniendo en cuenta que los dos papas Borgia siempre fueron representados con hábitos pontificales y no episcopales, parece más plausible pensar que ambos pudieran ser los dos obispos dominicos relacionados con este convento que estuvieron en la sede valenciana durante el siglo XIII: Andrés de Albalat y Ramón Despont.

En último lugar, en la Basílica de la Virgen de los Desamparados de Valencia se conservó, hasta la Guerra Civil, un lienzo de grandes dimensiones realizado en la primera mitad del siglo XVIII por Isidoro Tapia que se puede titular como el Árbol de la santidad valenciana, donde aparecen una gran cantidad de imágenes de santos, beatos y venerables valencianos. Esta obra hoy en día la conocemos por una fotografía que realizó Francisco Sanchis antes de dicho conflicto bélico, gracias a la cual se pudo realizar una copia fotográfica de grandes dimensiones que se ubicó en el mismo lugar que ocupaba en dicha basílica, aunque hoy en día ha sido retirada a los almacenes del Museo Mariano (MuMa).

El estudio de esta obra resulta muy complejo, por la gran cantidad de varones con fama de santidad representados -un total de 557- y porque las filacterias que figuran en la parte inferior de cada busto resultan ilegibles, impidiendo así la identificación segura de todos los personajes. ${ }^{68}$

La obra se divide en dos partes diferenciadas, en la central se recogen a los santos y venerables hijos de la ciudad de Valencia y en la exterior, a los del Reino de Valencia. En la parte central, en la quinta fila contando desde arriba, el séptimo personaje desde la derecha parece ser un cartujo y además parece ser el único cartujo entre todos los hijos de la ciudad de Valencia. ${ }^{69}$ Aunque conocemos un par de venerables de esta orden nacidos en Valencia, Jerónimo Frígola ( $† 1651)$ y Bonifacio Ferrer, todo apunta a que el personaje representado debería ser este último (Fig. 8). Según apunta Orellana, da a entender que Isidoro Tapia para realizar esta obra, u otra similar, tuvo que recorrer diferentes conventos y copiar los retratos de frailes ilustres en santidad que allí se hallaban, ${ }^{70}$ pero parece ser que no visitó ninguna cartuja, un tipo de edificio que se construía en lugares alejados de la población, puesto que no hay ningún otro cartujo en el lienzo. De esta manera, lo más probable es que este religioso sea Bonifacio Ferrer, debido a que existía al menos una imagen suya en la parroquial de San Esteban por estas fechas. Además, formalmente, el busto de Tapia aparece con una mano en el pecho y otra extendiéndola hacia un lateral, exactamente la misma posición que adopta la pintura atribuida a Domingo Saura.

\section{Cartuja de Valldecrist - Altura}

La memoria de Bonifacio también perduró en la zona de Segorbe-Altura por ser este el lugar donde permaneció sus últimos años, falleció y fue sepultado. Fray Bonifacio vivió en la cartuja de Valldecrist desde 1410, y además una leyenda local le atribuye la realización de la Virgen de la Cueva

\footnotetext{
${ }^{66}$ VILANOVA Y PIZCUETA, Francisco de Paula. Hagiografía Valenciana. Valencia: Impr. Gombau, Vicent y Masiá, 1912, p. 271.

67 CATALÁ GORGUES, Miguel Ángel, El pintor y académico José Vergara (Valencia 1726-1799). Valencia: Generalitat Valenciana, 2003, p. 227.

68 Sobre esta obra ver: FELICI CASTELL, Andrés, 2016 (nota 1), pp. 705-715.

${ }^{69}$ El hábito cartujo se puede confundir con relativa facilidad con el de la Merced en esta obra.

70 ORELLANA, Marcos Antonio, 1923 (nota 60), t. 1, pp. 304-305.
} 


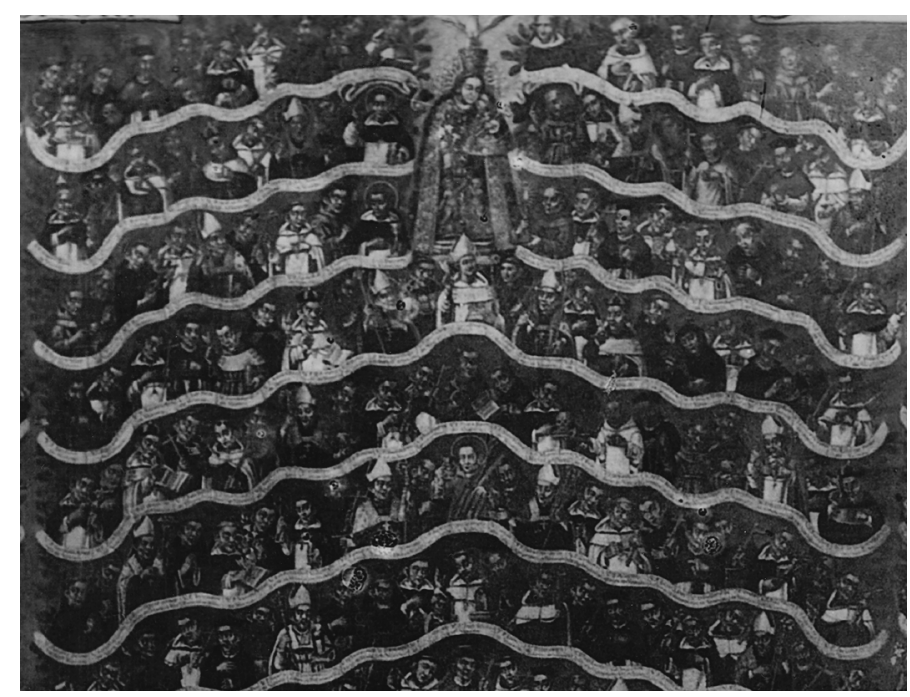

Fig. 8. Bonifacio Ferrer (en la quinta fila contando desde arriba, el séptimo personaje desde la derecha), detalle del $A r$ bol de la santidad valenciana, Isidoro Tapia, primera mitad del s. XVIII, Valencia, Basílica de la Virgen de los Desamparados, desaparecido en 1936. Copyright Estudio Fotográfico Sanchis 1901.

Santa, en cuyo santuario en la actualidad reposan sus restos. En toda esta zona podemos encontrar imágenes suyas, aunque realizadas en una época muy reciente.

El cementerio del monasterio de Valldecrist había sido consagrado el 18 de enero de 1415, y el primero en ser sepultado allí fue Bonifacio Ferrer. "Su sepultura es la que está más cerca de la Torre llama- da de las Almas, que está más salida que las otras y con una cruz de piedra a la ca[be]cera en todo diferente de las demás, toda llana y sin relieves. De esta sepultura nacen unas yerbas, con las cuales ha obrado el Señor algunos milagros por los merecimientos de su siervo don Bonifacio Ferrer, los quales refiere el Padre Alfaura (lib. 1, cap. 23)"..$^{71} \mathrm{El}$ mismo Joaquín Alfaura refiere que "por aver el Padre don Bonifacio hecho tantos milagros con las yerbas de su sepultura, por esso en la estampa de los Padres Generales que salió el año 1649 está pintado con unas yerbas a los pies, que son el símbolo de estas maravillas". ${ }^{72}$ Aunque aquí se citen unas hierbas como atributo del venerable, lo cierto es que en la actualidad no conocemos ninguna imagen donde porte dicho elemento. La orden cartuja siempre ha sido muy austera y rigurosa, y por tanto los restos de fray Bonifacio tuvieron una historia diferente a la que pudiera haber tenido cualquier otro venerable de la época. Sabemos que su cuerpo estuvo bajo tierra y en el año de 1600 , coincidiendo con las fiestas que se hicieron por haber traído desde Vannes una costilla de san Vicente, ${ }^{73}$ en un momento en que otras órdenes se estaban preocupando por rescatar la memoria de sus frailes ilustres, ${ }^{74}$ "quisieron los Monges de Valde-Christo elevar, y colocar su cuerpo en un sepulcro de marmol, pero lo resistió el Padre Dom Juan Bellot, como cosa insolita en la Cartuxa". ${ }^{75}$

Esta fecha coincide con un auge importante del culto a la Virgen de la Cueva Santa, cuyo santuario reclamaba como posesión la propia cartuja de Valldecrist, pero el pleito finalmente se resolvió a favor del obispado de Segorbe. ${ }^{76}$ Se sabe que el cuerpo

71 TEIXIDOR, José, 2013 (nota 8), p. 15. Ximeno, por su parte, indica que Bonifacio fue sepultado "en el Cimenterio del Claustro, cerca de la Capilla, en donde, como escrive Viciana, pusieron por señal una Cruz de piedra de dos brazos" [XIMENO, Vicente 1747 (nota 2), t. 1, p. 22]. Lo que escribió Viciana al respecto es lo siguiente: "Don bonifacio ferrer murió en este conuento e fue sepultado en el cemiterio consagrado. Y por señal pusieron una + de piedra de dos braços cabe la capilla del cemiterio". VICIANA, Martín de. Chronyca de la inclita y coronada de Valencia y de su reyno. Valencia: Juan Navarro, 1564, $3^{\text {a }}$ parte, fol. 61r.

72 TEIXIDOR, José, 2013 (nota 8), p. 15. Según indica el mismo Teixidor, hay que seguir estas indicaciones de los Anales manuscritos de la Cartuxa de Valldecrist de Joaquín Alfaura (†1672), monje profeso de dicho cenobio, puesto que conoció de primera mano el sepulcro, y no las que hicieron posteriormente otros autores: "Yaze su cuerpo en la Luna del Claustro de ValdeChristo, contestando el Cielo la santidad del difunto con una perenne maravilla, qual es, que de la tierra que cubre su cabeza sale una frondosa mata de azucenas, y se presume nace de su misma boca, y persevera por casi trecientos años, sin marchitarse, fresca siempre, y lozana, y valo contra varias enfermedades. De aqui en la estampa de los Generales de su Orden se le dá una mata de azucenas por divisa" [VIDAL MICÓ, Francisco, 1735 (nota 2), p. 420].

73 TEIXIDOR, José, 2013 (nota 8), p. 16.

${ }^{74}$ En el convento de Predicadores de Valencia, por ejemplo, se hallaron los restos del venerable Juan de Puigventós en 1598. En el mismo año el también venerable dominico Miguel de Bennazar fue devuelto a su sepultura original en la capilla de San Juan del convento de Mallorca, tras haber estado sus restos ocultos en la sacristía. En 1585 en el monasterio del Puig también fueron hallados los huesos del venerable Juan Gilabert Jofré.

75 VIDAL MICÓ, Francisco, 1735 (nota 2), p. 421.

76 "Tradiciones levantinas. Los peregrinos de la Cueva Santa". Estampa, 1928, n 50, s/p [También se puede consultar en: $<$ http://penyaramiro.blogspot.com.es/2013/09/la-cueva-santa-miradas-desde-el-pasado.html> (Fecha de consulta: 12-10-17)]. 
de Bonifacio reposó en dicha cartuja incluso después de la desamortización, hasta que el 13 de abril de 1895, tal vez por el miedo a que se pudieran perder sus restos debido a la situación de abandono que sufría el monasterio, fueron trasladados a la iglesia parroquial de Altura. ${ }^{77}$ Pocos años después, el 29 de abril de 1917, el obispo de Segorbe, el venerable Luis Amigó, trasladó el cuerpo de fray Bonifacio a la capilla de la Comunión del santuario de la Cueva Santa, ${ }^{78}$ debido a la leyenda que le atribuía como autor de la sagrada imagen, coincidiendo con el 500 aniversario del fallecimiento del venerable cartujo. ${ }^{79}$ Debido a la Guerra Civil, en 1936 los restos del venerable fueron profanados y destruidos, reconstruyéndose su tumba tras la contienda bélica. La sepultura original del religioso nunca gozó de ningún elemento decorativo, simplemente la cruz que citan las fuentes antiguas, debido a eso cuando se labró su nueva tumba en 1917, a cargo del franciscano Mateo Company y del escultor Miguel Romeo, ${ }^{80}$ no se incorporó ninguna imagen de fray Bonifacio, imitándose una estructura gótica y apeando el cuerpo rectangular del sepulcro sobre dos ménsulas con leones. En la parte visible al público se dispusieron tres escudos: a la izquierda el de la familia Ferrer, a la derecha el escudo de la cartuja de Valldecrist y al centro una cruz, el único elemento que se sabe que poseía su sepulcro original.

Según la tradición, la Virgen de la Cueva Santa fue realizada por Bonifacio Ferrer, aunque esta leyenda ${ }^{81}$ ya en los siglos XVII-XVIII fue muy cuestionada, ${ }^{82}$ adoptando los autores diferentes posturas. Por ejemplo, en una de las primeras obras donde se recoge la historia del santuario, realizada en 1655, ni tan siquiera se nombra a fray Bonifacio, aunque sí que se apunta que los monjes de Valldecrist solían hacer figuras de escayola de la

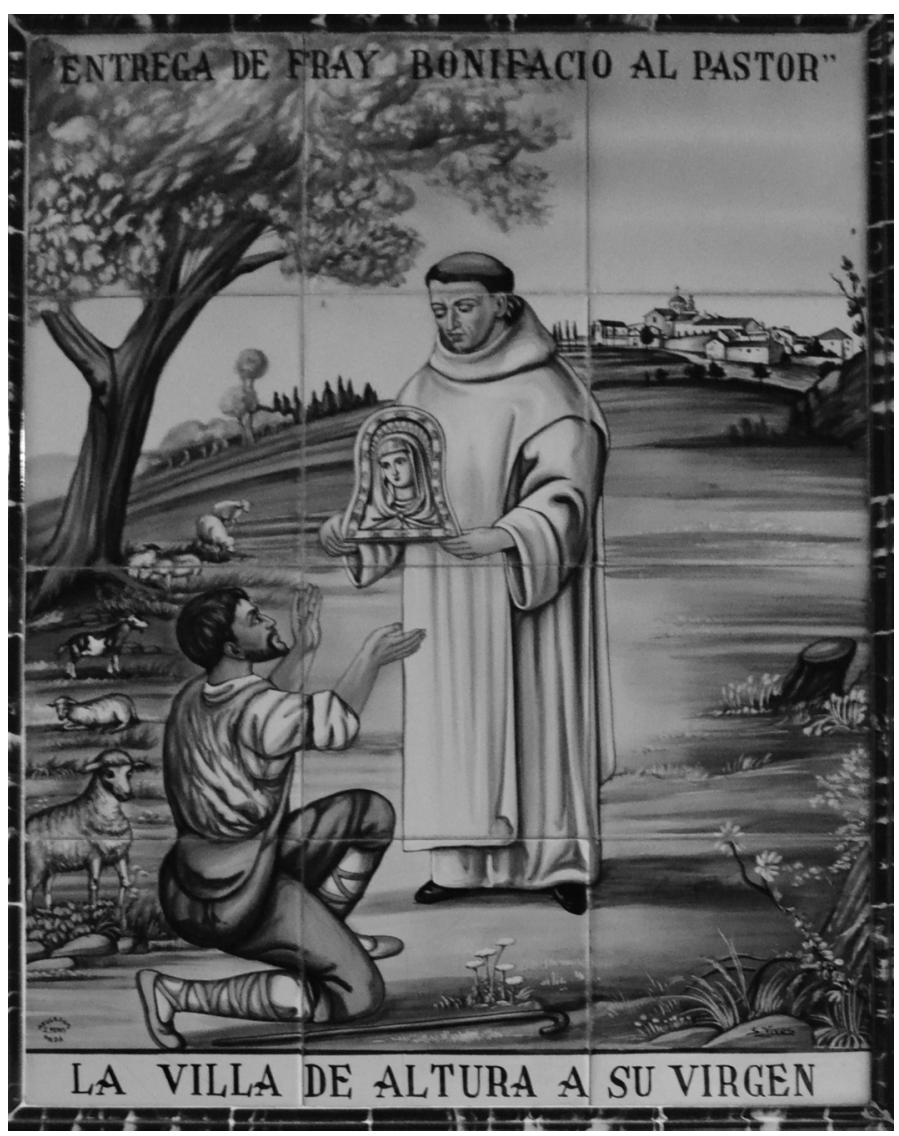

Fig. 9. Bonifacio Ferrer entregando la Virgen de la Cueva Santa a un pastor, Salvador Vives Roca, segunda mitad del siglo XX, Altura, santuario de la Cueva Santa.

Virgen para entregarlas a los pastores, conservándose de hecho los moldes en dicha cartuja. Una de aquellas copias sería la venerada en la cueva. ${ }^{83}$ Tal vez la tradición popular, para dar mayor im-

\footnotetext{
77 Según el acta correspondiente, el cuerpo estaba a dos metros y medio de profundidad, junto a la torre de las Almas. El esqueleto se puso en una caja y se entregó a las autoridades de Altura. MORRO FOSAS, Pedro. D., Bonifacio Ferrer. Su vida-sus obras. Segorbe, 1955, p. 136 [recogido también en ESPONERA CERDÁN, Alfonso (ed.), 2013 (nota 2), p. 173].

78 RODRÍGUEZ CULEBRAS, Ramón. "El arte religioso en la antigua diócesis de Segorbe de Trento a los nuevos tiempos". En: AA. VV., La Luz de las Imágenes. Segorbe. Generalitat Valenciana, 2001, p. 197.

79 MORRO FOSAS, Pedro. "Santuarios Importantes. La Cueva Santa". Los Santuarios Católicos - Órgano del Fomento Nacional de Peregrinaciones, octubre 1928, n 10, pp. 3 y ss [Texto reproducido también en <http://penyaramiro.blogspot.com.es/ 2013/06/la-cueva-santa-miradas-desde-el-pasado.html> (Fecha de consulta: 12-10-17)].

80 MORRO FOSAS, Pedro, 1955 (nota 77), p. 140 [recogido también en ESPONERA CERDÁN, Alfonso (ed.), 2013 (nota 2), p. 176].

81 La leyenda en sí dice que fray Bonifacio realizó el medallón de yeso de la Virgen y lo entregó a unos pastores para fomentar la devoción mariana. Esta efigie fue olvidada por ellos en una cueva, llamada del Latonero, en la cual solían guarecerse con sus ganados. Allí, a principios del siglo XVI, sería encontrada por otro pastor y la devoción hacia ella empezó a crecer, especialmente a partir de la curación de un leproso, iniciándose así la construcción de una capilla en dicho lugar. "Tradiciones levantinas. Los peregrinos de la Cueva Santa", 1928 (nota 59), s/p; PLANILLO PORTOLÉS, José Ángel, "La Cueva Santa: ¿iniciación, implantación o adaptación de un culto?". Boletín del Instituto de Cultura Alto Palancia, 2013, n²1, pp. $62-66$.

82 Ver: XIMENO, Vicente, Escritores del Reino de Valencia... Valencia: Joseph Estevan Dolz, 1749, t. 2, p. 236. En la actualidad también se sigue cuestionando esta tradicional autoría, ver: PLANILLO PORTOLÉS, José Ángel, 2013 (nota 81), pp. 57-100.

83 JUSTICIA, José de la. Historia de la Virgen de la Cueva Santa. Valencia: Bernardo Nogués, 1655, pp. 9-15.
} 


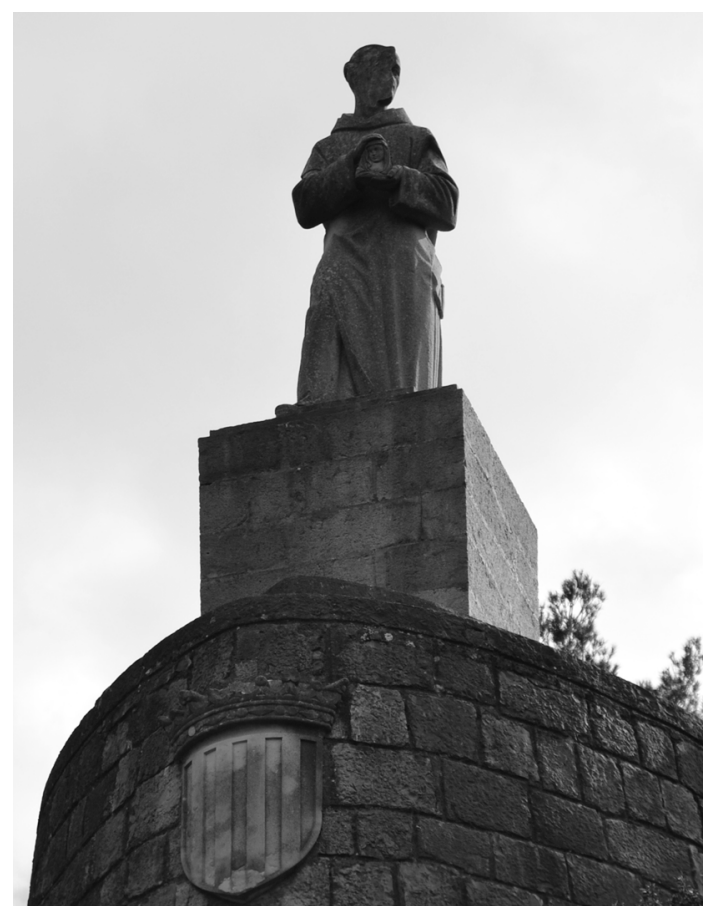

Fig. 10. Bonifacio Ferrer, Anónimo, 1955, Altura, inmediaciones del santuario de la Cueva Santa.

portancia a esta imagen, decidió que el monje cartujo que había realizado esta en concreto hubiera sido su morador más célebre, fray Bonifacio Ferrer. Esta leyenda sería definitivamente respaldada por la Iglesia con el traslado de los restos de su cuerpo que realizó el obispo Luis Amigó a dicho santuario en 1917.

Es a partir de esa fecha, aunque fundamentalmente después de la Guerra Civil, ${ }^{84}$ cuando podemos encontrar imágenes de este venerable en dicho santuario y su entorno. Así por ejemplo en el interior del templo se conservan un par de retablos cerámicos, uno de ellos donado por el obispo de Segorbe-Castellón José Pont y Gol, el cual se inspira en obras del siglo XVII que representan al venerable; y otro donado por la villa de Altura (Fig. 9), que recoge el momento de la entrega de la Virgen de la Cueva Santa a un pastor. Por otro lado el propio relicario de la Virgen de la Cueva Santa, labrado de nuevo tras la Guerra Civil, incorporó las figuras de Bonifacio y de un pastor, haciendo alusión a esa entrega de la imagen labrada por el venerable. Por otra parte, en las inmediaciones del santuario, a expensas del obispo José Pons y Gol, ${ }^{85}$ se construyó en 1955 un monumento a fray Bonifacio, en el que aparece representado portando la imagen de la Virgen de la Cueva Santa (Fig. 10), quedando situado en un lugar privilegiado desde el cual se contempla la sierra Calderona y la cartuja de Valldecrist. ${ }^{86}$ También se realizaría otro monumento del venerable en los restos del mismo cenobio, donde simplemente está el monje con su hábito, sin ningún otro atributo.

\section{Conclusiones}

Desde el mismo momento de su fallecimiento, Bonifacio Ferrer gozó de fama de santidad. En la cartuja de Valldecrist se vanagloriaron de poseer sus restos y por ello, dentro de la austeridad cartuja, buscaron dar cierta relevancia a su sepultura, intentando años más tarde trasladar sus huesos a un lugar más digno sin éxito. Como sus restos se hallaban sepultados en dicho monasterio, la vecina Portaceli, lugar de profesión del venerable, posiblemente consideró el retablo que él había encargado, y donde había sido representado, casi como una reliquia. Fue esta cartuja donde más importancia tuvo el culto a Bonifacio, el hijo más célebre del cenobio, pues aquí encontramos diversas imágenes suyas portando nimbo durante los siglos XVI-XVII -detrás de las cuales suele estar el padre Civera, gran devoto suyo-, y su retrato aparecerá a los pies de grabados de la Virgen de Portaceli hasta el siglo XIX. Mientras tanto, en Valencia, especialmente en la parroquia donde fue bautizado, San Esteban, también se buscará resaltar la figura del venerable,

\footnotetext{
${ }^{84}$ Para conocer el estado del santuario anterior al conflicto bélico, ver: SARTHOU CARRERES, Carlos, Viaje por los santuarios de la provincia de Castellón. Castellón de la Plana: Establecimiento Tipográfico de J. Armengot e Hijos, 1909, pp. 176-191 [Un resumen del mismo se puede encontrar en <http://penyaramiro.blogspot.com.es/2013/07/la-cueva-santa-miradas-desde-el-pasado.html> (Fecha de consulta: 12-10-2017)].

85 SABORIT BADENES, Pere, "La diócesis de Segorbe de Trento a nuestros días". En: AA. VV., La Luz de las Imágenes. Segorbe. Generalitat Valenciana, 2001, p. 75.

86 <http://www.upv.es/ csahuqui/lyscueva.html> (Fecha de consulta: 12-10-17). Este monumento, por la inscripción que posee, se erigió como "reparación" de los daños causados por la destrucción de sus restos en 1936. Así reza el texto de la base, en la parte posterior: "EN 1936 LOS [ROJOS] DESTRUYERON LOS RESTOS DEL AUTOR DE LA S. IMAGEN DE Na Sa DE LA CUEVA SANTA FR. BONIFACIO FERRER, LOS CUALES EN 1917 HABIA MANDADO DEPOSITAR EN SU SANTUARIO EL RVDMO. P. LUIS AMIGO, OBISPO DE SEGORBE. EN 1955 EL DR. D. JOSE PONT Y GOL, OBISPO DE LA MISMA DIOCESIS, MANDO ERIGIR ESTE MONUMENTO DE PIEDRA EN RECUERDO DEL VI CENTENARIO DE SU NACIMIENTO Y EN ACTO DE HOMENAJE Y REPARACION A LA PROCER FIGURA DEL HUMILDE CARTUJO. PARA PERPETUA MEMORIA".
} 
aunque de manera más discreta, entre otras cosas por el considerable número de santos y venerables que habían sido bautizados en su pila. El escaso culto que tuvo Bonifacio en Valencia siempre estuvo a la sombra del de su hermano san Vicente, y las imágenes que encontramos siempre suelen estar en relación con él. Con la desamortización en el siglo XIX y la exclaustración de las cartujas, el culto de Bonifacio en Portaceli cayó en el olvido, pero en cambio eso contribuyó a crear un nuevo foco en Altura y el santuario de la Cueva Santa, lugar donde se le veneró más por ser el ejecutor de la milagrosa imagen mariana que por ser considerado como santo. Las más recientes imágenes de Bonifacio proceden de este foco, que parece haber tomado el testigo de Portaceli, aunque con diferentes matizaciones.

Pese a que hoy por hoy iniciar un proceso de beatificación a Bonifacio Ferrer parece una utopía, lo bien cierto es que, a través de las imágenes, podemos constatar que entre los siglos XV-XVIII, para algunos Bonifacio fue considerado y venerado como un santo más, debido a lo cual su imagen se utilizó para legitimar o dar relevancia a algunas obras como la Biblia valenciana o la Virgen de la Cueva Santa, en las cuales históricamente no podemos confirmar su participación, hecho que ha contribuido a que su memoria haya permanecido viva ininterrumpidamente desde su fallecimiento hasta la actualidad. 
